\title{
CHANGES IN UNEMPLOYMENT AND WAGE \\ INEQUALITY: AN ALTERNATIVE \\ THEORY AND SOME EVIDENCE
}

\section{Daron Acemoglu}

\author{
Working Paper 6658 \\ http://www.nber.org/papers/w6658 \\ NATIONAL BUREAU OF ECONOMIC RESEARCH \\ 1050 Massachusetts Avenue \\ Cambridge, MA 02138 \\ July 1998
}

Any opinions expressed are those of the author and not those of the National Bureau of Economic Research.

(C) 1998 by Daron Acemoglu. All rights reserved. Short sections of text, not to exceed two paragraphs, may be quoted without explicit permission provided that full credit, including $(\mathbb{C}$ notice, is given to the source. 
Changes in Unemployment and Wage Inequality:

An Alternative Theory and Some Evidence

Daron Acemoglu

NBER Working Paper No. 6658

July 1998

JEL No. E24, J31, J64

\section{ABSTRACT}

This paper offers a model where firms decide what types of jobs to create and then search for suitable workers. When there are few skilled workers and the productivity gap between the skilled and the unskilled is small, firms create a single type of job and recruit all workers. An increase in the proportion of skilled workers or skill-biased technical change can create a qualitative change in the composition of jobs, increasing the demand for skills, wage inequality, and the unemployment rates for both groups. The paper provides some evidence that there has been a change in the composition of jobs in the U.S. during the past two decades.

Daron Acemoglu Department of Economics Massachusetts Institute of Technology E52-371 50 Memorial Drive Cambridge, MA 02138-5398 and NBER daron@mit.edu 
Between 1979 and 1987, the average weekly wages of college graduates with one to five years of experience increased by 30 percent relative to the average weekly earnings of comparable high school graduates (John Bound and George Johnson, 1992; Lawrence F. Katz and Kevin M. Murphy, 1992). Within group (residual) wage inequality may have started increasing earlier: after controlling for education and experience, the differential between the ninetieth and the tenth percentile wages stood at 118 percent in 1988 compared to 92 percent in 1970 (Chinhui Juhn, Murphy and Brooks Pierce, 1993). The rise in inequality over this period was not only due to wage increases for high paid workers. For example, real wages of high school graduates with 1 to 5 years of experience fell by 20 percent from 1979 to 1987 (Katz and Murphy, 1992, Table I). Meanwhile, the unemployment rates of all education groups have also increased. In 1970, the unemployment rate for civilian males between the ages of 25 and 64 with less than 4 years of high school stood at 4 percent. For those with high school and college degrees, the same numbers were 2.4 percent and 1.1 percent. Averaged between 1992 and 1994, the unemployment rates for these three groups were respectively 13.9 percent, 6 percent and 3.2 percent, approximately three times higher than the rates during the 1970's. ${ }^{1}$

This paper offers a theory in which these labor market developments may be caused by a qualitative change in the composition of jobs. Namely, in response to changes in the skill level of the labor force or technology, "middling" jobs open both to skilled and unskilled workers may be replaced by high quality (capital) jobs designed for the skilled and low wage jobs targeted at the unskilled. This change in the composition of jobs leads to higher skilled wages, lower unskilled wages, and higher unemployment rates for both skilled and unskilled workers. To the extent that skills are positively but imperfectly correlated with education, these changes imply higher returns to education, increased residual inequality and higher unemployment rates for all education groups.

The first possible driving force for the change in the composition of jobs is an increase in the proportion of skilled workers in the labor force. According to the standard approach, an increase in the relative supply of skills depresses the skill premium and reduces inequality. In contrast, in this model when the supply of skills reaches a critical threshold, it becomes more profitable to create jobs designed for skilled workers, and the composition of jobs undergoes a qualitative change, altering the structure of wages and unemployment. ${ }^{2}$ In 
other words, an increase in the supply of skills can create more than its own demand and increase inequality. The second possible driving force is an exogenous increase in the relative demand for skilled workers, which may be due to skill-biased technical change or increased international trade. In this case, the change in the composition of jobs emphasized in this paper is a novel economic mechanism for a familiar shock, enabling us to explain the fall in the wages of low-paid workers and the increase in unemployment for both skilled and unskilled workers, which are not features readily explained by existing theories.

There are two crucial ingredients in this paper. The first is the presence of search frictions, which makes it costly for firms to find suitable workers. John Barron, John Bishop and William Dunkelberg (1985), among others, document the costs of recruiting workers. These problems appear to be more serious when firms attempt to select skilled workers, especially given the imperfect correlation between education and skills. Similarly, the evidence in Topel and Michael P. Ward (1992) indicates that it takes a long time for young workers to find suitable jobs. The second ingredient is that firms have to choose what type of job to open before meeting a worker. This also appears plausible since in practice, a firm which has opened a service job cannot easily change it to a manufacturing job, nor can a firm easily downgrade its technology.

These two ingredients imply that the skill composition of the labor force affects the types of jobs that firms want to create. When the supply of skills is limited, it is not profitable to create jobs specially designed for the skilled, because it is difficult to find skilled workers and these jobs would not be as productive when employing unskilled workers. As a result, when there are few available skilled workers and there is a small gap between their productivity and that of the unskilled, the economy will be in a pooling equilibrium where firms create "middling" jobs, do relatively little screening and hire most applicants. Because in a pooling equilibrium both skilled and unskilled workers are employed in the same jobs with the same amount of physical capital, unskilled workers are employed at higher physical to human capital ratios than the skilled, and wage differentials are compressed. Also, because firms recruit most applicants, unemployment is low.

The alternative to pooling is a separating equilibrium in which firms create separate jobs for skilled and unskilled workers, and search for the appropriate candidates. Jobs for skilled workers are of a higher quality in a separating than in a pooling equilibrium, while 
unskilled jobs are of higher quality in a pooling equilibrium. As a result, in a separating equilibrium skilled workers earn more, and the unskilled less, than in a pooling allocation. Furthermore, since skilled workers produce only with high capital firms and the unskilled work only with low capital firms, the unemployment rates for both types of workers are higher. Starting from a pooling equilibrium, an increase in the proportion of skilled workers and/or skill biased technical change can push the economy to a separating equilibrium, changing the composition of jobs, reducing unskilled wages, and increasing skilled wages and unemployment rates for both groups.

Both possible driving forces of this theory are empirically plausible. Many studies argue that the past two decades witnessed rapid skill-biased technical change (e.g. Eli Berman, Bound and Zvi Griliches, 1994; David Autor, Katz and Alan Krueger, 1997). This period was also characterized by an unusually rapid increase in the supply of skills. For example, the ratio of college graduates to non-college graduates in the labor force increased by over 54 percent between 1970 and 1980. Finally, there is some evidence suggesting that there was a change in the composition of jobs in the U.S. between the 1970's and the 1990's, consistent with a shift from a pooling to a separating equilibrium. In particular, high wage firms are more selective in their hiring than they were two decades ago, the distribution of physical capital to labor ratios across industries have become more unequal, workers appear to be better matched to their jobs, the distribution of on-the-job training across education groups has become more unequal, and some of the jobs in industries and occupations which typically pay close to the median of the wage distribution have been replaced by jobs from the more extreme parts of the quality distribution of jobs. These patterns are consistent with the theory outlined above and suggest that changes in the composition of jobs may be an important component of the changes in the structure of wages and unemployment.

This paper builds on the search and matching models of Boyan Jovanovic (1979), Peter Diamond (1982)., Dale T. Mortensen (1982) and Christopher A. Pissarides (1990). In contrast to those and as in Michael Sattinger (1995), Kenneth Burdett and Melvyn Coles (1997) and Robert J. Shimer and Lones A. Smith (1997), workers and firms are ex ante heterogeneous. The approach in this paper, however, constitutes an improvement over these studies because the heterogeneity of firms is not assumed exogenous but is derived from their investment decisions. In this respect the model has a similarity to Acemoglu (1996), 
Acemoglu and Shimer (1997) and Steven J. Davis (1996) who also analyze models with ex ante investments. However, these papers do not discuss the changes in the composition of jobs, and do not allow for two sided heterogeneity. My paper is also related to the growing literature on the causes of wage inequality, including Kremer and Maskin (1997). They consider a model of assignment where workers of different skill levels form teams. If the distribution of skills is sufficiently disperse, a further increase in the variance of skills may induce high skill workers to produce with other high skill workers and increase inequality. Their approach is therefore complementary to but different from this paper. In particular, in their model there are no firms (independent from workers), so there is no change in the composition of jobs and the recruitment practices of firms, which are at the heart of my paper. There is also no unemployment (hence no change in unemployment). Furthermore, in the data there is basically no increase in the variance of skills which is the driving force in Kremer and Maskin's paper whereas there is a large increase in the supply of skills which is one of the driving forces in this paper. Finally, in more recent work (Acemoglu, 1998), I extend the approach in this paper and point out another reason why an increase in the supply of skilled workers may increase inequality: when technical change is endogenous, an increase in the supply of skills increases the market size for skillcomplementary technologies, and may induce skill-bias technical change.

The plan of the paper is as follows. Section I uses a static model to expose the main ideas. While this model clarifies the economic forces at work, it has a number of special features. Section II considers a dynamic and more standard framework which avoids these special features, and enables me to discuss how the approach in this paper can account for different dimensions of the changes in the structure of wages. Section III provides some evidence of a change in the composition of jobs in the U.S.. Section IV concludes, and the Appendix contains the proofs of the main results.

\section{A Static Model}

In this section, I start with the simplest model of endogenous job composition. Although the phenomena I am interested in are dynamic, I first use a static model to present the main results. In this economy, firms choose what type of jobs to open and then search 
for workers. I show that there exist two types of equilibria with different structures of jobs and wages: pooling and separating. In the pooling equilibrium, firms open "middling" jobs and recruit all workers. In the separating equilibrium, firms create jobs designed for high skill workers. I show how changes in the relative supply of skills and/or in technology can switch the economy from a pooling to a separating equilibrium, transforming the structure of wages and unemployment.

\section{A. Preferences, Technology and the Walrasian Allocation}

There is a mass 1 of risk-neutral workers and a mass 1 of risk-neutral and profitmaximizing firms. The economy lasts for one period. A fraction $\phi$ of the workers are skilled and the remaining $1-\phi$ are unskilled. It is useful to distinguish between education and skills. A fraction $\nu$ of the workers are highly educated (e.g. college graduates) and the remaining $1-\nu$ have low education (e.g. high school graduates). A highly educated worker has a probability $\kappa_{H}$ of being skilled while the same probability is $\kappa_{L}<\kappa_{H}$ for a worker with low education, so $\phi=\kappa_{H} \nu+\kappa_{L}(1-\nu)$. I normalize the human capital of unskilled workers to $h=1$ and the human capital of skilled workers is $h=\eta>1$.

Production takes place in one firm-one worker pairs. A worker with human capital $h$ and a firm with capacity $k$ produce:

$$
y(h, k)=A k^{1-\alpha} h^{\alpha}
$$

The timing of events is as follows. First, each firm has to choose its capacity ("physical capital"), $k$, irreversibly. This choice captures the type of job the firm has designed and the line of business it has chosen, and is assumed to be costless. ${ }^{3}$ At this point, the firm does not know the type of the worker it will recruit. Next, the firm matches with a worker, finds out his type, and decides whether to shut down or continue. If it continues, it installs the required equipment and incurs a cost $c k$. Finally, wages are determined.

The Walrasian allocation of this economy corresponds to the case where at the wage determination stage, firms and workers can switch partners at no cost, and workers receive their full marginal product. In equilibrium, a fraction $\phi$ of firms choose $k^{L}=$ $a c^{-1 / \alpha}$ and the remaining $1-\phi$ fraction choose $k^{H}=a \eta c^{-1 / \alpha}$ where $a \equiv[(1-\alpha) A]^{1 / \alpha}$. The Walrasian mechanism allocates skilled workers to high capacity firms and maximizes 
output. Since workers receive their full marginal product, skilled wages are: $w^{H}=$ $y\left(\eta, k^{H}\right)-c k^{H}=\alpha a \eta /\left[(1-\alpha) c^{(1-\alpha) / \alpha}\right]$, and unskilled wages are $w^{L}=y\left(1, k^{L}\right)-c k^{L}=$ $\alpha a /\left[(1-\alpha) c^{(1-\alpha) / \alpha}\right]$, so the skill premium is equal to $w^{H} / w^{L}=\eta$.

\section{B. Equilibrium With Costly Search}

Consider a trading environment with frictions and without the Walrasian auctioneer to mediate trade. Firms and workers come together randomly. Random matching implies that high and low capacity firms are equally likely to meet skilled workers. ${ }^{4}$ I also assume that each firm meets one worker and vice versa. Once they meet, the worker-firm pair have to decide whether to produce together. In the dynamic version of the model, if the worker and the firm do not agree, they continue to search for a new partner, whercas here, because the economy lasts only for one period, the firm produces no output, and the worker receives zero income. Recall that at the wage determination stage, the firm has already sunk the cost of capital, $c k$. Therefore, if the firm and the worker agree, they will share total output $y(h, k)$. I assume that the worker obtains a fraction $\beta$ of this amount, and the firm obtains the remainder. Hence, wages conditional on the amount of capital are: $w^{H}(k)=\beta A k^{1-\alpha} \eta^{\alpha}$ and $w^{L}(k)=\beta A k^{1-\alpha}$ where the superscript $H$ denotes a skilled worker and $L$ denotes an unskilled worker. To simplify the algebra, I also set $c \equiv(1-\beta)$.

The expected value of a firm choosing capacity $k$ can be written as:

$$
V\left(k, x^{H}, x^{L}\right)=\phi x^{H}(1-\beta)\left[A k^{1-\alpha} \eta^{\alpha}-k\right]+(1-\phi) x^{L}(1-\beta)\left[A k^{1-\alpha}-k\right],
$$

where $x^{j}$ is the equilibrium probability that the firm produces with a worker of type $j=L$ or $H$, conditional on matching with this worker. Since a fraction $\phi$ of workers are skilled and there is random matching, the firm produces with a skilled worker with probability $\phi x^{H}$, and obtains $(1-\beta) y(\eta, k)-c k=(1-\beta)\left[A k^{1-\alpha} \eta^{\alpha}-k\right]$. The secend part of (2) is explained similarly. Note that when the firm decides not to produce with the worker, i.e. $x=0$, it does not incur the cost of capital, $c k$.

In this static economy, workers are passive: they accept any match that comes along (since the alternative is to obtain zero). Therefore, an equilibrium is simply a distribution of capacity choices represented by the function $F(k)$ over some support $\mathcal{K}$, and two acceptance functions $x^{H}(k)$ and $x^{L}(k)$ such that for all $k^{\prime} \in \mathcal{K},\left(k^{\prime}, x^{H}\left(k^{\prime}\right), x^{L}\left(k^{\prime}\right)\right) \in$ 
$\arg \max _{k, x^{H}{ }_{1} x^{L}} V\left(k, x^{H}, x^{L}\right)$. The next proposition characterizes the equilibria in this static economy (proof in the Appendix).

\section{Proposition 1: If}

$$
\eta<\left(\frac{1-\phi}{\phi^{\alpha}-\phi}\right)^{1 / \alpha}
$$

then, there is a unique equilibrium which is pooling. All firms choose

$k^{P}=a\left[\phi \eta^{\alpha}+(1-\phi)\right]^{1 / \alpha}$, i.e. $\mathcal{K}=\left\{k^{P}\right\}$, and $x^{H}\left(k^{P}\right)=x^{L}\left(k^{P}\right)=1$.

If $\eta>\left[(1-\phi) /\left(\phi^{\alpha}-\phi\right)\right]^{1 / \alpha}$, there is a unique equilibrium which is separating. All firms choose capacity $k^{H}=a \eta$, i.e. $\mathcal{K}=\left\{k^{H}\right\}, x^{H}(k)=1$ and $x^{L}(k)=0$.

The first type of equilibrium is called pooling because firms choose the same amount of capital and "pool" across the two types of workers. In this equilibrium, unskilled workers have higher physical to human capital ratios $\left(k^{P}\right)$ than skilled workers $\left(k^{P} / \eta\right)$. This differential in physical to human capital ratios compresses the wage differential to $w^{H} / w^{L}=\beta y\left(\eta, k^{P}\right) / \beta y\left(1, k^{P}\right)=\eta^{\alpha}$, which is lower than the wage differential in the Walrasian allocation, $\eta$. There is no unemployment in the pooling equilibrium because each worker meets a firm and they always agree. In the separating equilibrium, firms create separate jobs for skilled workers and turn down the unskilled, and skilled workers earn more than they did in the pooling equilibrium, because firms targeting the skilled choose a larger capacity, i.e. $k^{H}>k^{P}$, and so $w_{\text {pool }}^{H}=\beta a\left[\phi \eta^{\alpha}+(1-\phi)\right]^{(1-\alpha) / \alpha} \eta^{\alpha} /(1-\alpha)<$ $w_{\text {sep }}^{H}=\beta a \eta /(1-\alpha)$. In contrast, in a separating equilibrium, the earnings and employment of the unskilled collapse.

Figure 1 draws equation (3) in the space of $\phi$ and $\eta$. It is a downward sloping curve because a pooling equilibrium requires both $\phi$ and $\eta$ to be relatively small. Changes in these two variables give the main comparative static results of the paper. To interpret these results note that an increase in $\phi$ corresponds to an increase in the proportion of skilled workers in the labor force, which may be due to an improvement in the educational attainment of the labor force, $\nu$, or to changes in the curriculum of high schools and colleges increasing the fraction of skilled workers in the two education groups, $\kappa_{L}$ and $\kappa_{H}$. An increase in $\eta$ is equivalent to skill-biased technical change because it increases the productivity of capital when combined with skilled workers but does not affect the productivity 
of capital used with unskilled workers. ${ }^{5}$ It can also be viewed as an increase in the relative price of goods produced by skilled workers resulting from opening to international trade.

To focus on the most interesting comparative statics, I consider an economy in the pooling equilibrium and analyze the impact of an increase in $\phi$ and $\eta$.

1) As long as we are inside Region I (pooling equilibrium) in Figure 1, an increase in $\phi$ has no effect on wage inequality, which remains at $w^{H} / w^{L}=\eta^{\alpha}$. If $\phi$ continues to increase, eventually the economy switches from Region I to Region II, where the equilibrium is separating. The switch creates a qualitative change in the structure of the labor market: middling jobs open to both types of workers are replaced by high capacity jobs designed for skilled workers, skilled wages increase, and unskilled employment and wages collapse.

2) An increase in $\eta$ always increases wage inequality. However, as long as we stay in Region I, unskilled wages also increase with $\eta$. In contrast, when the change takes the economy from Region I to Region II, once again skilled wages jump up, amplifying the direct impact of $\eta$ on $w^{H}$, and unskilled employment and wages collapse.

Increases in $\phi$ and $\eta$ raise unskilled wages when the economy remains in Region I, because they increase $k^{P}$, the level of capital that the unskilled work with (Acemoglu, 1996). Yet both changes hurt unskilled workers when the cconomy switches from pooling to separating equilibrium. Therefore, the impact of the supply of skills and technical change on unskilled workers is non-monotonic. In interpreting these results, it is also worth bearing in mind that in the dynamic model, similar results will be obtained, but the separating equilibrium will also involve low capital jobs designed for the unskilled. As a result, when the economy switches from a pooling to a separating equilibrium, the unemployment rates for both types of workers will increase. Finally, observe that since there are skilled workers in both education groups $\left(\kappa_{H}, \kappa_{L}>0\right)$, but a larger fraction among high education workers $\left(\kappa_{H}>\kappa_{L}\right)$, when the economy switches from a pooling to a separating equilibrium, both residual wage inequality and returns to education increase (see Section II.D for more details). 


\section{An Alternative Theory of U.S. Labor Market Changes}

In the light of the comparative static results, the developments in the U.S. labor markets during the late 1970's and the 1980's can be given a different interpretation. Recall that neither the existing skill-biased technical change stories nor others that have been advanced readily predict: (i) the fall in unskilled wages; (ii) the increase in the unemployment rates of all workers (for this see next section); (iii) a change in the composition of jobs. As pointed out in the introduction, the first two features have accompanied the recent increase in wage inequality, and Section III will provide detailed evidence that there has been a change in the composition of jobs.

First, suppose that, as many believe, the past twenty five years were characterized by skill-biased technical change, raising $\eta$. The increase in $\eta$ can move the economy from a pooling to a separating equilibrium and create a qualitative change in the composition of jobs, reducing unskilled wages and increasing wage inequality and unemployment. As noted above, an increase in the prices of skill intensive goods due to international trade, another popular driving force for the rise in earnings inequality, would have the same effects.

A more novel explanation for the U.S. labor market trends also emerges from this simple model, because an increase in $\phi$ induces the same changes in unemployment and inequality. When skilled workers are more abundant, firms find it profitable to design jobs for them rather than pool across the two skill groups. This transforms the structure of the labor market, increasing returns to education, residual inequality and unemployment. Moreover, as opposed to skill-biased technical change, an increase in $\phi$ is directly observed in the data. For example, Autor, et al. (1997) construct the changes in the employment share of college graduates. This share increased by 6 percentage points between 1950 and 1970. In contrast, it increased much faster, by 11.6 percentage points, from 1970 to 1990 . Since more educated workers are more likely to be skilled, this change translates into a large increase in the supply of skills. This increase in skills was also at least partly exogenous rather than a simple response to anticipated higher returns to skills in the future. College enrollments had been increasing since the 1950's, and the large cohort sizes of the baby boom generation implied that these high enrollment rates had a large effect on the skill composition of the labor force during the 1970's. Two other factors also contributed by 
increasing enrollments even further during the 1960's and the early 1970's: (i) Vietnamera draft laws exempted males enrolled in college from military service and induced many more young males to stay in college in order to avoid the draft (see Lawrence M. Baskir and William Strauss, 1978); (ii) government financial aid for college increased by a large amount during this era. The total government aid to college students, which stood at approximately 2 billion dollars in 1963, increased to $\$ 14$ billion in $1970-71$ and to $\$ 24$ billion in 1975-76 (in 1989-90 dollars, see Michael S. McPherson and Morton O. Schapiro, 1991). Therefore, in terms of the model, we can think of $\phi$ incrcasing exogenously. A simple relative supply-demand approach would predict a decline in the relative wages of skilled workers. However, in the data the large increase in the supply of skills during the 1970's is followed by a rise in the skill premium. In contrast to the conventional approach, my theory predicts that even if technological possibilities remain unchanged, an increase in the proportion of skilled workers can switch the economy from a pooling to a separating equilibrium and increase inequality.

\section{A Dynamic Model}

I now describe the dynamic version of the enviromment of Section I. When the economy switches from pooling to separating equilibrium, there will now be low capacity jobs targeted at the unskilled as well as the high capacity jobs designed for the skilled, and the unemployment rate of skilled workers will increase.

\section{A. Technology, Preferences and the Walrasian Allocation}

Consider a continuous time economy populated by a mass 1 of infinitely lived riskneutral agents, discounting the future at the rate $r$. A fraction $\phi$ of these agents are skilled, with human capital $h=\eta>1$, and the remaining $1-\phi$ fraction are unskilled with $h=1$. As in the static model, $\phi$ is related to the underlying distribution of educational attainment and to the correlation between schooling and skills.

On the other side of the market there is a larger mass of risk-neutral firms, also discounting the future at the same rate $r$. Each firm can employ at most one worker and is in one of three states: inactive, unfilled vacancy and filled job. Inactive firms obtain a 
payoff of 0 , and can rent a site to open a vacancy. There are $\theta \geq 1$ sites and the flow rental price of a site is $r \gamma$, which will be determined in equilibrium. Unfilled vacancies meet an unemployed worker at the instantaneous rate $q$, and unemployed workers meet a vacancy at the rate $p ; p$ and $q$ are assumed exogenous, and $p, q<\infty$ so that decentralized trading takes time.

At every instant, some of the existing firms exit and new firms rent their sites. Immediately upon renting a site, and before meeting a worker, each firm has to design a job and choose its capacity, $k$. As in the static model, this (irreversible) capacity choice captures the type of job created and its quality, and the firm incurs no costs until matching. New and old unfilled vacancies search for workers and upon meeting a worker, they decide whether to employ the worker and whether to buy the necessary equipment at the cost $C k$. This capital cost is incurred only once, but if the worker leaves the relation, the equipment becomes obsolete. Finally, the worker and the firm negotiate the wage rate. At the wage determination stage, the cost of capital is already sunk. If the firm and the worker reach an agreement, they produce flow rate of output given by (1) in the previous section; otherwise, they continue to search for new partners. The capital equipment of each firm breaks down at the instantaneous rate $s$, and in this event, the firm exits the market, the worker becomes unemployed, and the production site is rented to a new firm.

Before characterizing the equilibrium with costly search, it is instructive to construct the Walrasian allocation where trade takes place at a full market-clearing price vector announced by the auctioneer at time 0 . Recalling that $a \equiv[(1-\alpha) A]^{1 / \alpha}$ :

Proposition 2: In any Walrasian equilibrium, $\tilde{\theta} \in[1, \theta]$ firms are active and all workers are employed. A fraction $1-\phi$ of active firms choose $k^{L}=a[(r+s) C]^{-1 / \alpha}$ and produce with unskilled workers. The remaining $\phi$ fraction choose $k^{H}=a \eta[(r+s) C]^{-1 / \alpha}$ and produce with skilled workers. In any equilibrium, $w^{H}=A\left(k^{H}\right)^{1-\alpha}-(r+s) C k^{H}$, $w^{L}=A\left(k^{L}\right)^{1-\alpha^{L}}-(r+s) C k^{L}, w^{H} / w^{L}=\eta$, and $\gamma=0$.

The proof of this proposition is omitted. Although firm choose their capacity before the production stage, the Walrasian trading process and the large number of potential firms (i.e. $\theta>1$ ) ensure that workers receive their full marginal product, which in this case is the flow rate of output, $y(h, k)$, minus the discounted cost of capital. Since capital equipment 
breaks down at the rate $s$, the effective discount factor is $r+s$. The wage differential between skilled and unskilled workers is exactly equal to the skill differential: $w^{H} / w^{L}=\eta$. Notice also that there is a high degree of "separation", i.e. different jobs for skilled and unskilled workers, because high capital firms have a higher willingness to pay for skilled workers, so employ them in equilibrium (see Sattinger, 1993).

\section{B. Equilibrium with Costly Search}

I now turn to the analysis of the search economy where matching is random, so that firms with different capacities have the same likelihood of meeting skilled workers. Throughout the paper, I limit the analysis to steady states and only write the Bellman equations that apply in steady state. I also denote the fraction of workers in the unemployment pool who are skilled by $\lambda$. This will in general differ from $\phi$ because the two types of workers may have different job finding rates. Then:

$$
r V(k)=q\left[\lambda x^{H}\left(J^{H}(k)-C k-V(k)\right)+(1-\lambda) x^{L}\left(J^{L}(k)-C k-V(k)\right)\right] .
$$

Intuitively, $V(k)$ is the asset value of a vacancy with capacity $k$ (more formally, this should be $V\left(k, x^{H}, x^{L}\right)$ but I suppress the latter arguments to simplify the exposition). This vacancy receives no revenue in its current state but meets a worker at the flow rate $q$. Random matching implies that with probability $\lambda$, the worker is skilled, and the pair decide to produce together with probability $x^{H}$. In this case, the firm relinquishes the value of its current state, $V(k)$, incurs the cost of capital, $C k$, and obtains $J^{H}(k)$, the value of a firm with capacity $k$, producing with a skilled worker. Alternatively, it meets an unskilled worker at the flow rate $q(1-\lambda)$, agrees to produce with him with probability $x^{L}$, and obtains $J^{L}(k)-C k-V(k)$.

With a similar logic, the asset values for a matched firm are:

$$
r J^{j}(k)=A k^{1-\alpha} h_{j}^{\alpha}-w^{j}(k)-s\left(J^{j}(k)-\gamma\right)
$$

where $j=H, L$. Recall that the capital equipment breaks down at the flow rate $s$, and in this case, the firm exits the market and stops paying the rental price of the site, hence the term $\gamma$ in the last expression. I denote the distribution of capacity choices among vacancies 
by $F(k)$ and its support by $\mathcal{K}$. The asset values for unemployed workers are:

$$
r U^{j}=p \int_{\mathcal{K}} x^{j}(k)\left(W^{j}(k)-U^{j}\right) d F(k),
$$

for $j=H, L$, where $W^{j}(k)$ is the value of a worker of type $j$ employed by a firm with capacity $k$, and $x^{j}(k)$ is the probability that a worker of type $j$ and a firm with capacity $k$ agree to produce together. Intuitively, a worker receives nothing when unemployed, but at the flow rate $p$, he meets a vacancy with capacity randomly drawn from the distribution $F(k)$. Also, the values for employed workers are:

$$
r W^{j}(k)=w^{j}(k)-s\left(W^{j}(k)-U^{j}\right) .
$$

Because trading is a costly process, matched pairs have a quasi-rent to be shared. I assume that wages are determined by bargaining with alternating offers. ${ }^{6}$ Namely, if $r\left[U^{j}+V(k)\right]>A k^{1-\alpha} h_{j}^{\alpha}$, then worker $j$ and a firm with capacity $k$ would break up the relation. Otherwise, the wage is:

$$
w^{j}(k)=\max \left\langle r U^{j} ; \min \left\{\beta A k^{1-\alpha} h_{j}^{\alpha} ; A k^{1-\alpha} h_{j}^{\alpha}-r V(k)\right\}\right\rangle,
$$

where $\beta$ is the bargaining power of the worker. In words, this wage rule states that the worker and the firm divide the flow return of the match, $A k^{1-\alpha} h_{j}^{\alpha}$, with shares $\beta$ and $1-\beta$, unless the return to one of the parties is less than what they could obtain by not agreeing. The cost of capital investment does not feature in this wage rule because it is already sunk, and the outside option of the firm is $r V(k)$, because in case of a disagreement, it will look for a new worker, and its capital will become obsolete.

Finally, from steady state accounting, we have:

$$
\begin{gathered}
u^{j}=\frac{s}{s+p \int_{\mathcal{K}} x^{j}(k) d F(k)}, \\
\lambda=\frac{\phi u^{H}}{\phi u^{H}+(1-\phi) u^{L}},
\end{gathered}
$$

where $j=H, L, u^{j}$ is the unemployment rate of workers of type $j$, and $\lambda$ is the fraction of skilled workers in the unemployment pool.

A steady state search equilibrium is a tuple $\left\langle F(k), \mathcal{K}, x^{L}(k), x^{H}(k), \lambda, u^{H}, u^{L}, \gamma\right\rangle$ such that $V(k), J^{j}(k), U^{j}$ and $W^{j}(k)$ satisfy $(4),(5),(6)$ and $(7)$ for $j=H, L$, wages are given by (8), and the following conditions hold: 
1. (Optimal capacity decision): for all $k \in \mathcal{K}, k \in \arg \max _{k^{\prime}} V\left(k^{\prime}\right)$.

2. (Free entry): for all $k \in \mathcal{K}, V(k)=\gamma$.

3. (Optimal agreement): for all $k \in \mathcal{K},\left(x^{L}(k), x^{H}(k)\right) \in \arg \max V(k)$.

4. (Steady state accounting): $u^{H}, u^{L}$ and $\lambda$ satisfy (9) and (10).

In a steady state equilibrium firms make optimal capacity choices, the rental market for production sites clears (free-entry), and agreement decisions are optimal. The next proposition establishes that an equilibrium exists, and gives some details about capacity choices and acceptance decisions. To simplify the expressions, I normalize $C \equiv(1-\beta) /(r+s)$.

Proposition 3: A steady state equilibrium exists. In any equilibrium, the support of the capacity distribution among vacancies, $\mathcal{K}$, has at most three elements, $k^{L}, k^{P}$ and $k^{H}=a \eta$, and we have: $x^{L}\left(k^{L}\right)=1, x^{H}\left(k^{L}\right)=0, x^{L}\left(k^{P}\right)=1, x^{H}\left(k^{P}\right)=1, x^{L}\left(k^{H}\right)=0$ and $x^{H}\left(k^{H}\right)=1$.

The proof of this proposition is given in the Appendix. In equilibrium, there are at most three different levels of capacity, and one of these, $k^{H}$, is equal to $a \eta$, and is chosen by firms which only produce with skilled workers. $k^{L}$ maximizes (4) when $x^{H}=0$ and $x^{L}=1$, and is chosen by firms which only produce with unskilled workers. Finally, $k^{P}$, the capacity choice of firms producing with both types of workers, maximizes (4) with $x^{H}=x^{L}=1$.

\section{Pooling and Separating Equilibria}

I now characterize the steady state equilibria in more detail. I denote the fraction of vacancies with capacities $k^{L}, k^{P}$ and $k^{H}$ by $\mu^{L}, \mu^{P}$ and $\mu^{H}$. A pooling steady state equilibrium is an allocation where $\mu^{P}=1$, so that all firms create middling jobs with capacity $k^{P}$ and recruit all workers they meet. In this equilibrium, $u^{H}=u^{L}$ and $\lambda=\phi$. Because all jobs have the same capacity, workers' outside options do not bind (and the Appendix shows that firms' outside options never bind), so the wage rule (8) becomes $w(h, k)=\beta A k^{1-\alpha} h^{\alpha}$. The maximization of (4) yields $k^{P}=a\left[(1-\phi)+\phi \eta^{\alpha}\right]^{1 / \alpha}$, and so $V\left(k^{P}\right)=q(1-\beta) \alpha a\left[(1-\phi)+\phi \eta^{\alpha}\right]^{1 / \alpha} /[(1-\alpha) r(r+s+q)]=\gamma$. The condition for the 
steady state equilibrium to take this form is that there should be no profitable deviation, especially by a firm choosing $k^{H}$ and employing only skilled workers. Therefore, we need $V\left(k^{H}\right)<\gamma$ (and also $V\left(k^{L}\right)<\gamma$ which is automatically satisfied). Substituting $x^{H}=1, x^{L}=0, \lambda=\phi$ and $k^{H}=a \eta$ in (4) and (5), we obtain $V\left(k^{H}\right)=$ $q \phi(1-\beta) \alpha a \eta /[(1-\alpha)(r+s)(r+q \phi)]+q \phi s \gamma /[(r+s)(r+q \phi)]$. Simple algebra then gives the condition for a pooling equilibrium to exist as:

$$
\eta \leq\left[\frac{(1-\phi)(r+s+q \phi)^{\alpha}}{(r+s+q)^{\alpha} \phi^{\alpha}-(r+s+q \phi)^{\alpha} \phi}\right]^{1 / \alpha} .
$$

This parallels (3) from the previous section and is drawn in Figure 2. Intuitively, a pooling equilibrium requires that firms find it profitable to employ skilled and unskilled workers in the same type of job, which will be profitable if the productivity differential between the two types of labor, $\eta$, is small. Also, the strategy of choosing a higher capacity and searching for skilled workers, which is the main alternative to pooling, will be less profitable when there are few skilled workers, i.e. when $\phi$ is small. Hence (11) traces a downward sloping curve.

Three important features of the pooling equilibrium are: (i) there is only one type of job with capacity, $k^{P}$, which employs both skilled and unskilled workers. Therefore, as noted in Section I, skilled workers are employed at a lower capacity (capital) to human capital ratio $\left(k^{P} / \eta\right)$ than unskilled workers $\left(k^{P}\right)$; (ii) as a result of the first observation, wage differentials are compressed $-w^{H} / w^{L}=\beta A\left(k^{P}\right)^{1-\alpha} \eta^{\alpha} / \beta A\left(k^{P}\right)^{1-\alpha}=\eta^{\alpha}$ is less than $\eta$, the wage differential in the frictionless model; (iii) since all firms are the same and accept all workers, both groups have the same unemployment rate, $u^{H}=u^{L}=u_{\text {pool }} \equiv s /(p+s)>0$.

As in the static model, another possibility is a separating equilibrium. Firms create jobs with capacity $k^{H}$ for skilled workers and $k^{L}$ for the unskilled. In this equilibrium, $\mu^{P}=0$, and $\lambda$ is no longer equal to $\phi$. Also, observe that since there is only one type of job open to each worker, outside options are once again non-binding along the equilibrium path, so (8) becomes $w^{j}(k)=\beta A k^{1-\alpha} h_{j}^{\alpha}$. For the equilibrium to entail $\mu^{L}>0$, the expected values of opening vacancies with capacity $k^{H}$ and with capacity $k^{L}$ have to be equal, that is $V\left(k^{H}\right)=V\left(k^{L}\right)=\gamma$. Using equations (4) and (5) for $j=H, L$, this implies:

$$
\frac{\lambda \eta}{r+s+q \lambda}=\frac{1-\lambda}{r+s+q(1-\lambda)} \text {. }
$$


(12) solves uniquely for $\lambda^{*}(\eta)$, and together with, (10) determines $\mu^{H}$. Now we can see that a separating equilibrium with $\mu^{L}>0$ will exist if: $V\left(k^{P}\right) \leq \gamma=q \lambda^{*}(\eta)(1-$ $\beta) \alpha a \eta /\left[(1-\alpha) r\left(r+s+q \lambda^{*}(\eta)\right)\right]$, where $V\left(k^{P}\right)$ is the maximized value of (4) when $x^{L}=$ $x^{H}=1$ (see the Appendix for the determination of $k^{P}$ in this case). This inequality is likely to hold when both $\eta$ and $\phi$ are relatively low, thus defining another downward sloping curve in Figure 2. Finally, for $\phi$ and $\eta$ sufficiently high, in Region $V$, there exist (pure) separating equilibria in which $\mu^{L}=0$, so that no jobs are opened for unskilled workers (see the Appendix for the relevant conditions).

In the separating equilibrium: (i) skilled workers work with more capital, but physical to human capital ratios are equalized; (ii) there is no wage compression: $w^{H} / w^{L}=$ $\beta A\left(k^{H}\right)^{1-\alpha} \eta^{\alpha} / \beta A\left(k^{L}\right)^{1-\alpha}=\eta$, and so there is more wage inequality in the separating equilibrium than in the pooling equilibrium. While skilled workers obtain higher wages in the separating equilibrium, i.e. $w_{\text {sep }}^{H}>w_{\text {pool }}^{H}$, the unskilled receive less, i.e. $w_{\text {sep }}^{L}<w_{\text {pool }}^{L}$. This is because in the separating equilibrium, firms targeting the unskilled choose capacity $k^{L}<k^{P}$, so unskilled workers use less capital and earn less; (iii) the unemployment rates for both groups are higher than in the pooling equilibrium, because high capacity firms do not accept unskilled workers, and the skilled prefer to wait for jobs designed for them.

Separating and pooling equilibria are not the only possibilities. There can also be "mixed equilibria" with $\mu^{P}, \mu^{H}>0$, where some firms choose $k^{P}$ and pool, while others choose $k^{H}$ and only accept skilled workers. In this equilibrium, there is higher unskilled unemployment than $u_{\text {pool }}$, but since all firms accept skilled workers, skilled unemployment is still equal to $u_{\text {pool }}$. Unskilled wages are lower in the mixed equilibrium than in the pooling equilibrium, because $k^{P}$ is now less than $a\left[(1-\phi)+\phi \eta^{\alpha}\right]^{1 / \alpha}$ since $\lambda<\phi$, and wage inequality is higher because some of the high skill workers are employed in high capacity jobs designed for them, earning $w_{s e p}^{H}=\beta a \eta /(1-\alpha)$. Finally, there are multiple equilibria in the part of the parameter space denoted as Region III in Figure 2. The intuition for the multiplicity is as follows: when there are separate jobs for skilled workers, their outside option may be high enough that a firm which deviates to a lower capital level, $k^{P}$, will have to pay the outside option of skilled workers. This reduces profits from deviation and cnsures a separating equilibrium. In contrast, when other firms also choose $k^{P}$, the outside options of skilled workers do not bind, and choosing $k^{P}$ is more profitable than targeting 
only the skilled, and this makes the pooling allocation an equilibrium.

The comparative static results from Figure 2 are similar to those from Figure 1. An increase in $\eta$ always raises wage inequality, and may take us from a pooling to a separating equilibrium. An increase in the supply of skills as captured by a rise in $\phi$ can also switch the economy to a separating equilibrium, perhaps via Regions III and IV. If such a switch takes place, skilled wages jump up, unskilled wages fall, and both unemployment rates increase. Therefore, the main differences from Section I are that unskilled employment and wages do not collapse completely and the unemployment rate for skilled workers also increases. In the parametrized example drawn in Figure 2, as $\phi$ or $\eta$ increases, the economy is likely to switch from Region I (pooling equilibrium) briefly to Region IV (mixed equilibrium) or to Region III (multiple equilibria), and then to Region II (separating equilibrium). In the former case, the unemployment rate of the unskilled will increase, their wages will fall, and wage inequality will increase, and when the economy eventually switches to Region II or V, wage inequality will rise further, and the unemployment rate of skilled workers will also increase. If the economy first enters Region III, the equilibrium may continue to be pooling, and then the economy will switch to the separating equilibrium upon entering Region II and both the structure of wages and unemployment rates will change simultaneously. Finally, it is possible to perform other comparative statics. Changes in $A$ have no effect as they influence all returns in the same way. A high level of $p$ increases the parameter region of separating equilibrium because, when escape from unemployment is easier, skilled workers become less willing to accept middling jobs. A lower level of $\alpha$ also makes a separating equilibrium more likely because the increased degree of diminishing returns to human capital makes the pooling strategy less attractive.

\section{Residual Wage Inequality and Returns to Experience}

As briefly discussed in the introduction, returns to education increased during the 1980's. Residual wage inequality also increased over the same time period, perhaps starting as early as the 1970's. At a general level, higher residual wage inequality means that certain skills which are not observed easily (at least by the econometrician) are being rewarded more, which fits naturally with a story where firms have become more selective and screen 
more intensively. Specifically, the model in this paper predicts that returns to education and residual wage inequality should increase at the same time. There are two reasons for this. First, there are skilled workers both among college graduates and high school graduates. When the economy is in a pooling equilibrium, a fraction $\kappa_{H}$ of high education workers (and a fraction $\kappa_{L}$ of low education workers), who are skilled, obtain $w_{\text {pool }}^{H}$ while the rest receive $w_{\text {pool }}^{L}$. In the separating equilibrium, these two groups receive $w_{\text {sep }}^{H}$ and $w_{\text {sep }}^{L}$, which are more unequal, and residual wage inequality increases. ${ }^{7}$ Further, because $\kappa_{H}>\kappa_{L}$ (i.e. education and skills positively correlated), the return to education also rises. Before the switch, the return to education, $\omega$, defined as the average wage of college graduates divided by average non-college wage, is $\omega_{\text {pool }}=\left[\kappa_{H} w_{\text {pool }}^{H}+\left(1-\kappa_{H}\right) w_{\text {pool }}^{L}\right] /\left[\kappa_{L} w_{\text {pool }}^{H}+\left(1-\kappa_{L}\right) w_{\text {pool }}^{L}\right]$. After the switch to the separating equilibrium, the return to education rises to $\omega_{\text {sep }}=$ $\left[\kappa_{H} w_{\text {sep }}^{H}+\left(1-\kappa_{H}\right) w_{\text {sep }}^{L}\right] /\left[\kappa_{L} w_{\text {sep }}^{H}+\left(1-\kappa_{L}\right) w_{\text {sep }}^{L}\right]>\omega_{\text {pool }}$, because $\kappa_{H}>\kappa_{L}$.

To discuss the second reason why returns to education and residual inequality are related, consider an extension of the basic model. In search models, "luck" plays an important role as some workers draw a high wage while others end-up with a low wage. The simple set-up I used so far allowed luck to influence life-time carnings through duration of unemployment and employment ( $p$ and $s$ ), but not wages (except for skilled workers in the mixed equilibrium). To allow for a more general matching technology incorporating this feature, suppose that skilled workers are more likely to meet high capacity firms. In particular, consider the following matching technology: with probability $\chi$, a skilled worker is matched with a relatively high capacity firm, and with probability $1-\chi$, he matches randomly. The same applies to firms. The previous version of the paper demonstrated that as long as $\chi<1$, the main results from the previous sections continue to hold, but there is an equilibrium distribution of capacity choices (rather than simply one or two capacities). Some workers will draw a high wage from the distribution of jobs open to them, and there will be a distribution. of wages for workers of the same skill level due to pure luck. In a separating equilibrium, the distribution of capacity choices is more disperse than in a pooling equilibrium, so there is more wage dispersion among identical workers and greater residual wage inequality.

A final dimension of the incrcase in incquality during the 1980's is the higher return to experience. This is not predicted by the model in this paper, but a simple extension suggests 
that it is not inconsistent with the approach developed here. Imagine a version of the model where new workers arrive at the flow rate $\delta$. Also suppose that firms cannot terminate the relation with an existing worker or renegotiate the wage, but workers can quit. In this case, as the composition of jobs changes, unskilled workers who are currently in pooling jobs will be protected until they eventually lose their jobs, and the burden will fall on the young unskilled, increasing returns to experience. The reverse phenomenon does not happen as much for skilled workers because, when the economy switches to a separating equilibrium, many of them would leave their pooling jobs for higher capital ones. It is interesting to note that, consistent with this view, returns to experience increased substantially among high school graduates, but not among college graduates (see Katz and Murphy, 1992).

\section{Some Evidence}

The theoretical analysis established that a change in the composition of jobs could be responsible for the U.S. labor market trends taking place since the late 1970's. I now offer a variety of evidence suggesting that there was a change in the composition of jobs. Most individual pieces of evidence are open to alternative interpretations, and the changes may have been caused by technology, the increase in the supply of skills, or other factors. Nevertheless, together this evidence paints a picture consistent with the approach in this paper, and suggests that the changing composition of jobs may be an important component of the changes in the structure of wages.

\section{A. Changing Recruitment Practices of Firms}

The first piece of evidence I want to offer is that there has been a change in the recruitment practices of firms. In my model, the pooling equilibrium is a situation where firms recruit all applicants. In contrast, in the separating equilibrium, firms with high capital only accept the skilled. Therefore, we should observe more screening and "selectiveness" on the part of firms. Although human resource practitioners whom I talked with agree that there is more screening now than twenty years ago, there are relatively little data to back this up. The increased spending by companies on their own human resource departments and human resource consulting firms is consistent this view, but does not prove it. 
The most suggestive evidence comes from case studies. Richard J. Murnane and Frank Levy (1996) report their interviews with human resource personnel at a number of companies. A manager at Ford Motor company in 1967 describes their hiring strategy as follows: "If we had a vacancy, we would look outside in the plant waiting room to see if there were any warm bodies standing there. If someone was there and they looked physically OK and weren't an obvious alcoholic, they were hired" (p. 19). Ford at the time was a high wage employer, and its lack of screening can be interpreted as a pooling strategy: it realized that some of the workers would be less productive, but it still chose to recruit them because it was not profitable to search and wait for more skilled workers. In contrast, similar companies in the late 1980's appear to use a very different recruitment strategy. Murnane and Levy discuss the cases of Honda of America, Diamond Star Motors and Northwestern Mutual Life. These are high wage employers, with somewhat higher real wages than Ford in the 1960's, and the first two are in the same industry as Ford. All three companies spend substantial resources on recruitment and hire only a fraction of those who apply. The first two use formal cognitive tests, including mathematics, aptitude and English tests as well as a series of lengthy interviews. The third company employs more intensive interviews but no formal tests. The interview process in all three companies is quite costly as it involves a large number of fellow employees and managers, but they view this as a worthwhile activity. Although there may be different interpretations for these trends (e.g. the increased importance of team production), a plausible interpretation is that firms are no longer happy to "pool" across different skills, and they want to hire only high skill workers for their relatively high quality jobs. Moreover, in line with the theory in this paper, not all employers are following this hiring strategy. Murnane and Levy discuss the case of another company, Sports Plus, which employs assemblers. It pays between $\$ 5.50$ and $\$ 7.00$ per hour, offers little training, and basically hires every applicant without any screening.

The results of Peter Cappelli and Stephanie Wilk (1997) are also of interest in this context. They employ a new data set of 2,945 establishments to analyze the determinants of hiring practices and intensity of screening of production workers. Of most interest for this paper's focus, they look at how average wages of production workers, average education of production workers, the reported level of skill-requirements of jobs, and the fraction of workers using computers covary with hiring practices. They find that each of these four 
variables has a statistically significant and robust positive effect on selection intensity, and the component of screening that increases most in response to these variables is selection on education and ability (as opposed to experience or recommendation). Therefore, firms using more computers and more skills, which are also the ones offering higher wage jobs, spend more resources on screening in order to find workers that have the required level of education and are generally "skilled". These results are cross-sectional and cannot be directly extrapolated to changes from the 1970's to the 1990's. Nonetheless, combined with the case study evidence, they suggest that the widespread increase in computer use (Autor et al.1997) and rising skill requirements (Cappelli, 1996, and Murnane and Levy, 1996) are likely to have been associated with increased screening.

\section{B. Changes in Mismatch between Jobs and Workers}

In a pooling equilibrium high and low skill workers are employed in the same jobs using the same quality equipment. Therefore, skilled workers, employed at the physical to human capital ratio $k^{P} / \eta$, are "over-skilled" for their job, while the unskilled, working at the physical to human capital ratio $k^{P}$, are "under-skilled". In contrast, in a separating equilibrium, both types of workers are employed at the physical to human capital ratio $a$ where $k^{P}>a>k^{P} / \eta$. So, workers are better matched to their jobs in separating equilibrium than in pooling equilibrium. Although the forces I discuss may be less important for eduction than for other dimensions of skills, because schooling is observable, making search for educated workers relatively easy, in a world of costly search and imperfect correlation between skills and education, there will be educational mismatch in the labor market, and more so in a pooling equilibrium. Therefore, the approach in this paper predicts less overand under-education during the 1980's than in the 1970's.

There is a large literature on overeducation in the labor market. The most interesting and careful paper in this literature is by Nachum Sicherman (1991) who studies data from the Panel Study of Income Dynamics (PSID) in response to the question: "how much formal education is required to get a job like yours?". He constructs over- and under-education variables by subtracting the response to this question from actual education. He finds that workers who report to be overeducated for their job earn less than others with the same 
amount of education, but more than workers with less education doing the same job. This is reversed for undereducated workers. Moreover, overeducated workers switch to higher wage jobs more quickly than others, suggesting that they are truly overeducated for their jobs, rather than less skilled in some other dimension unobserved to the econometrican. These findings are consistent with this paper's predictions: on average, overeducated workers are those working with lower physical to human capital ratios; they earn less than workers with the same education, but more than others with lower education working with the same amount of physical capital.

The question on required education in the PSID is asked in 1976, 1978 and 1985. Sicherman pools the three years. Here I repeat this exercise separately for each year to see whether the amount of over- and under-education (mismatch) has changed from mid 1970's to 1980 's. ${ }^{8}$ First, results not reported here confirm that Sicherman's findings hold in each year, and the coefficients in these cross-sectional regressions, except the return to schooling, are quite similar, suggesting that there has not been a major change in the interpretation of these questions by the respondents. The key results for my hypothesis are reported in Table 1. The sample includes male heads of households between the ages 18 and 60 , who are currently in employment or temporarily laid-off, excluding the self-employed. No other sample restrictions are applied. The first part of Table 1 reports the number and fraction of workers who have their last grade completed within the bracket of required education (exact), those who have more education than required for their jobs (overeducated), and those with less education than required (undereducated) for each year. The columns 4 to 6 give the mean years of overeducation for each group, with standard errors in parentheses. Recall that overeducation is defined as actual minus required education; a negative number means that required education for that group exceeds actual education. Finally, the last two rows give the variance and average absolute deviation of the overeducation variable.

The results in Table 1 show that both the amount and variance of overeducation have decreased. The proportion of workers who have exactly the required education for their job has increased from less than 43 percent in 1976 to over 46 percent in 1985 . This increase is significant at 1 percent. Also, the average number of years of schooling that an overeducated worker has beyond what is required for his job has declined from 1976 to 1985 , which also suggests that workers are better matched to their jobs in 1985 than 
during the 1970's. The changes from 1976 to 1978 are insignificant at 10 percent whereas all the changes from either 1976 or 1978 to 1985 are once again significant at 1 percent. Also corroborating this picture, the cross-sectional variance of overeducation fell from 11.6 in 1976 to 9.1 in 1985 and the average absolute deviation fell from 2.4 to 1.8 . In both cases this drop of over 20 percent is statistically significant at 1 percent. Therefore, these numbers suggest that there is less mismatch in the 1980's than during the 1970's.

An alternative explanation for this finding is that firms hire through "ports-of-entry", and as a result, young workers are overeducated for their jobs. If there are fewer young workers in 1985, overeducation will have declined. To investigate this, I restricted the sample to either young workers or to those with short tenure. The results were very similar and in fact, stronger. In particular, restricting the sample to those between the ages 18 and 45, I found that in 1976, 43 percent of workers had exactly the required education. This number increased to 47 percent in 1985. Restricting the sample to those with less than 35 months of tenure, 39 percent of workers had exactly the required years of education in 1976 , and this fraction had risen to 45 percent by 1985 . Therefore, it appears that there is a significant decline in educational mismatch between 1976 and 1985, which is consistent with a switch from a pooling to a separating equilibrium, and more generally, with increased screening and selection by employers.

\section{Changes in the Distribution of Jobs}

In this subsection, I provide some evidence that "middling" jobs have been replaced by jobs from more extreme parts of the quality distribution. The difficulty with this exercise is to define and rank jobs. A reasonable first pass is to use industry-occupation cells to represent job categories, and rank them according to average wages (or average residual wages after controlling for worker characteristics). In this case, middling jobs would correspond to industry-occupation cells which pay close to the median of the wage distribution. Having ranked job categories, changes in the distribution of employment across the cells can be analyzed to see whether in the late 1980's there is more weight in the cells at the tails of the quality distribution of jobs than earlier. This approach may underestimate the change in the distribution of jobs if a substantial fraction of the shift 
from middling to high and low quality jobs took place within narrow industry-occupation cells, but there is no easy way of analyzing changes in job composition within these cells.

I use the Annual Earnings File of the Current Population Survey (CPS, Outgoing Rotation Group files uniform extract of the National Bureau of Economic Research) from 1983 to 1993 (the information refers to the previous year) to study the changes in the distribution of jobs. I limited the sample to those who are employed or temporarily out of work and between the ages 18 and 60 . I also excluded everyone who reported less than $\$ 1$ or more than $\$ 100$ hour wage and all those who are in the agriculture, forestry, fishing, armed forces and public administration.. The years before 1983 cannot be used because industry and especially occupation classifications are non-comparable.

I constructed cells using 19 major industries (excluding public administration, armed forces, forestry and agriculture) and 12 one digit occupation categories. I excluded the cells that contained less than 200 workers between 1983 and 1993. This gave a total of 174 cells, containing over 72 percent of total employment in the CPS. Although it is possible that workers in a given cell are performing very different jobs in 1993 than they were in 1983, this seems unlikely to be true for a large fraction of the 174 cells. In fact, average cell wages are very highly correlated across years. Therefore, in terms of the model one can consider each cell as a separate job category corresponding to a different level of $k$. In the model, a worker with given characteristics obtains a higher wage in a job with higher $k$. This suggests that we can rank cells according to residual wages from 1983 to 1993, and interpret the higher rank cells as containing higher quality jobs. More precisely, consider the regression of real wages on four education dummies, sex, race, a quartic in experience, and a dummy for those living in a metropolitan area, and let $\omega_{i t}$ be the average residual in cell $i$ and year $t$. Then, I calculate $\bar{\omega}_{i}=\sum_{t} \omega_{i t}$ and rank cells in ascending order according to $\bar{\omega}_{i}$ (so cell ranks are the same in all years). The average correlation of $\bar{\omega}_{i}$ with $\omega_{i t}$ is 0.95 , suggesting that there are no major changes in the distribution of residual wages across cells. Observe also that the increase in wage inequality from 1983 to 1993 does not imply anything about how the distribution of employment across cells should have changed. For example, the changes in inequality could have taken place within cells, and the distribution of employment across cells may have remained unchanged.

Table 2 reports the cumulative percentage of employment in the corresponding year 
at the cells with 10 th, 25 th, 50 th, 75 th and 90 th percentile ranks. Formally, let $e_{i t}$ be the percentage of the (restricted) sample employment in year $t$ and cell $i$. Then, for all $t$, $\sum_{i=1}^{N} e_{i t}=100$ where $N$ is the number of cells (in this case $N=174$ ). Also recall that if $i>i^{\prime}$, then average residual wage in cell $i$ is higher than in $i^{\prime}$, i.e. $\bar{\omega}_{i}>\bar{\omega}_{i^{\prime}}$. The cumulative percentage at the 25 th percentile in year $t$ is then equal to $\sum_{i=1}^{N / 4} e_{i t}$, and the 75 th percentile is equal to $\sum_{i=1}^{3 N / 4} e_{i t}$. For example, the number 79.5 at the 75 th percentile in 1993 implies that in this year, 20.5 percent of employment is in the quarter of the job categories with the highest average residual wages. The last column of Table 2 reports "weight at the tails", WT, defined as the cumulative percentage at the 25th percentile plus one minus the cumulative percentage at the 75 th percentile. ${ }^{9}$ That is, $W T_{t} \equiv \sum_{i=1}^{N / 4} e_{i t}+\sum_{i=3 N / 4}^{N} e_{i t}$. This measure therefore gives the total percentage of workers employed in the top 25 percent and bottom 25 percent cells, and is plotted in Figure 3. An increase in $W T$ implies that middling jobs have been replaced by jobs that are typically either higher or lower quality.

Table 2 and Figure 3 show that 35 percent of employment was in the top and bottom 25 percent job categories. By 1993, this number had risen to just under 38 percent. So, approximately 2.5 percent more workers now have either higher or lower quality jobs rather than middling jobs. These changes are not due to business cycle variations: the years 19831984 were at a similar stage of the business cycle to 1992-1993. It is possible that even more major changes in job composition, and hence in $W T$, took place before 1983, but due to changes in the occupation and industry codes, this is not straightforward to study.

To investigate the sources of this finding, I looked at the changes for men and women separately, and also analyzed the changes by education group (in all cases maintaining the same ranking of cells as above). For men, there is an increase of 1.5 percentage points in $W T$ from 36.3 percent to 37.7 percent between 1983 and 1993. For women, the increase is approximately 4 percentage points, from 33.7 percent to 37.5 percent. Among education groups, the largest changes are for those with high school or less. WT for this group increases by 3 percentage points, and most of this increase is at the lower tail. WT for college graduates increased by over 1 percentage point, mostly at the upper tail. Interestingly, there is no increase in $W T$ for those with some college.

To check the robustness of the results, I repeated the exercise by ranking cells according to average wages (rather than average residual wages). The results are unchanged; WT 
increases from 52.2 percent in 1983 to 54.1 percent in 1993. When I exclude cells that have less than 20 observations in any year (rather than only those with less than 200 in total), the number of cells is reduced to 161 , and $W T$ increases from 34.5 percent in 1983 to 36.9 percent in 1993. I also performed the same calculations using different levels of aggregation (and once again ranking the cells according to residual wages). Using one digit industry as above but 72 occupation categories, ${ }^{10}$ I obtain 576 cells with over 67 percent of the total CPS employment. In this case, WT increases from 40.3 percent in 1983 to 42.7 percent in 1993. The increase in $W T$ from 1983 to 1993 is approximately 2 percentage points for men, 4 percentage points for women, 3 percentage points for workers with high school or less, and 2 percentage points for college graduates. When I use two digit occupation and two digit industry, there are 865 cells containing over 65 percent of CPS employment, and $W T$ in this case shows an increase from 53.2 in 1983 to 55.3 percent in 1993.

Finally, to investigate longer term changes, I looked at census data on 138 industries from 1970 to $1990 .{ }^{11}$ I do not know of any consistent occupation codes for these years, so I only analyzed the changes in the industrial composition of employment. Ranking these 138 industries according to average wages between 1970 and 1990, WT was 43.2 percent in 1970, 42.4 percent in 1980 and increased to 43.9 percent in 1990. To compare this increase to the results from the CPS data, I created cells using only three digit industries, which gave 189 cells, containing 70 percent of total CPS employment. In this case, WT increases from 50.5 percent in 1983 to 51.8 percent in 1993. Therefore, the census and CPS results using industries only are similar, which is reassuring. But the changes are also somewhat smaller than the CPS other results, which suggests that a significant fraction of the change in job composition is within industries and that these latter measures underestimate the change in the distribution of jobs.

Overall, these results suggest that there were significant changes in the composition of employment during the 1980's and the early 1990's whereby job categories which typically pay close to the median of the wage distribution were replaced by higher and lower quality jobs, which is the pattern predicted by a switch from a pooling to a separating equilibrium. 


\section{Changes in the Distribution of On-the-Job-Training}

To study another dimension of the change in the quality distribution of jobs, one can look at how on-the-job-training has changed. Workers who obtain training receive higher wages, and more advanced and expensive equipments generally require more training. If unskilled workers are now working with less capital and the skilled with more, we might expect such a change to be reflected in the distribution of on-the-job-training. Since skills are unobserved, I looked at the distribution of training across education categories.

Jill M. Constantine and David Neumark (1994) analyze data from the CPS Supplements of 1983 and 1991, and report the following figures for "training to improve skills on the current job". In 1983, 18 percent of those with less than high school received any type of "training to improve skills on the current job". The same proportion was 33 percent for high school graduates, 43 percent for those with some college, and 55 percent for the college graduates. These numbers indicate that the distribution of training was very unequal across the education groups in 1983. But in the next eight years, it became even more unequal: in 1991, 17 percent of those without high school, 35 percent of high school graduates, 45 percent of those with some college, and 63 percent of college graduates received such training. Although Constantine and Neumark show that the changes in training only account for a small fraction of the changes in wage inequality, this process is indicative of changes in the composition of jobs. In fact, this pattern is consistent with the view that the composition of jobs has been changing, and the more skilled (educated) workers have been the winners in this process.

\section{E. Changes in Physical Capital and Labor Ratios}

Another implication of my model is that the amount of physical capital workers produce with should become more heterogeneous as we move from a pooling to a separating equilibrium. Recall that the dispersion of physical to human capital ratios falls (due to the same reason that mismatch falls), but when instead of looking at human capital, we look at capital per employee, we see that in a pooling equilibrium all workers are employed at capital $k^{P}$, while in a separating equilibrium, some use $k^{H}$ while others use $k^{L}<k^{H}$. Therefore, the dispersion of capital to labor (as opposed to human capital) ratios should increase 
around the same time as the switch from pooling to separating equilibrium. Francesco Caselli (1998) also constructs a theory which predicts the same outcome (though not the other predictions discussed here). To provide evidence in favor of this pattern, Caselli calculates measures of dispersion of the ratio of dollar value of equipment divided by total employment for 450 four digit manufacturing industries. Caselli's Figure 3a reports the log difference between the 90th and 10th percentiles of the distribution of the ratio of dollar value of equipment capital to employment across these 450 industries, which is reproduced here as Figure 4. It shows that the dispersion of equipment capital to labor is fairly constant until 1980's, and then starts increasing rapidly. The capital-labor ratio difference between the 90th and 10th most capital intensive industries has increased by 17.5 percent between 1975 and 1990. ${ }^{12}$ Caselli (1997) also shows that industries which increased their capital-labor ratio were the ones paying higher wages during the 1970 's, and they were also more likely to increase their average wages further and hire more skilled workers (nonproduction workers). These findings are consistent with the view that beginning in the late 1970's, some jobs targeted skilled workers and became more capital intensive, while other industries, which already employed less skilled workers, reduced capital per employee as implied by a switch from a pooling to a separating equilibrium.

\section{Concluding Remarks}

This paper has offered a model with an endogenous composition of jobs. In the model economy, firms decide what types of jobs to create and then search for workers. When there are relatively few skilled workers and the productivity gap between the skilled and the unskilled is limited, the equilibrium is pooling: firms create one type of -middlingjob and pool across different skill levels. When the productivity gap between the skilled and the unskilled increases or when the proportion of skilled workers in the labor force rises, the economy may switch to a separating equilibrium with higher quality jobs designed for the skilled and low capital jobs targeted at the unskilled. This qualitative change in the composition of jobs reduces unskilled wages, increases the earnings of the skilled and increases the unemployment rates for both types of workers.

Either one of two developments may have triggered a switch from a pooling to a sepa- 
rating equilibrium: (i) the proportion of college graduates in the U.S. labor force increased substantially over the past twenty five years; (ii) as many economists believe, new technologies or increased international trade may have increased the marginal product of skilled workers more than that of the unskilled during this period. The resulting transformation of the composition of jobs leads to higher returns to education, greater residual wage inequality, lower wages for unskilled workers and higher unemployment for all education groups, and may therefore be an important component of the changes in unemployment and wage inequality in the U.S. With a simple extension, this theory also explains the changes in the returns to experience. The paper also provided a variety of evidence consistent with the notion that there have been changes in the composition of jobs since the 1970's.

A number of important issues are not covered in this paper:

1) The evidence presented in Section III suggests that there was a change in the composition of jobs, but does not distinguish between different driving forces. Since the mechanism offered in the paper should apply in local labor markets, analyzing the changes in the composition of jobs in different U.S. states and how they vary with the supply of skilled workers may be a fruitful area for further work.

2) Endogenizing education choices is also an obvious next step. Since the presence of more skilled workers may increase the skill premium, the model can easily generate multiple equilibria. Further, in this case, relatively small shocks to the cost of education may have large effects on the supply of skills. With such an extension, the story of the paper would apply even if Vietnam-era draft laws and government aid for college during the 1970's only had a small effect (see also Acemoglu, 1998).

3) An important area of research is to explain the different experiences of the U.S. and Continental Europe. For example, Germany has not experienced an increase in wage inequality and until the unification, no significant change in unemployment (see Nickell and Bell, 1995). The theory in this paper suggests that the training system in Germany may be an important factor. Because training increases the human capital of less skilled (educated) workers, a developed training system may make the strategy of creating separate jobs for the skilled less profitable and a pooling equilibrium more likely. More generally, the impact of labor market institutions on job composition is another area for further research. 


\section{Appendix}

Proof of Proposition 1: An equilibrium $\left(k^{\prime}, x^{H}\left(k^{\prime}\right), x^{L}\left(k^{\prime}\right)\right)$ maximizes (2). Consider the first-order condition of (2) with respect to $k$ for given $x^{L}$ and $x^{H}$ :

$$
(1-\beta)(1-\alpha)\left[\phi x^{H}\left(A k^{-\alpha} \eta^{\alpha}-1\right)+(1-\phi) x^{L}\left(A k^{-\alpha}-1\right)\right]=0
$$

When $x^{H}=x^{L}=1$, (A1) solves for $k^{P}$ in the text, and yields a maximal value of $V^{P} \equiv$ $V\left(k^{P}, x^{H}=1, x^{L}=1\right)=(1-\beta) \alpha a\left[\phi \eta^{\alpha}+(1-\phi)\right]^{1 / \alpha} /(1-\alpha)$. Alternatively, for $x^{H}=1$ and $x^{L}=0$, (A1) solves for $k^{H} \equiv a \eta$ and yields $V^{H} \equiv V\left(k^{H}, x^{H}=1, x^{L}=0\right)=(1-$ $\beta) \alpha a \phi \eta /(1-\alpha)$. Next note that $V\left(k, x^{H}<1, x^{L}=1\right)<V^{P}$, and $V\left(k, x^{H}<1, x^{L}=\right.$ $0)<V^{H}$. Now, comparing $V^{P}$ and $V^{H}$ gives condition (3). Finally, when (3) holds, $V\left(k, x^{H} \leq 1, x^{L}<1\right)<V^{P}$ and when (3) does not hold, $V\left(k, x^{H} \leq 1, x^{L}<1\right)<V^{H}$, which completes the proof that either the pooling or the separating allocation is the unique equilibrium.

Proof of Proposition 3: I will first state and prove a lemma, which is part of Proposition 3. I will then prove that a steady state equilibrium exists.

Lemma A1: In any equilibrium, $\mathcal{K}$ has at most three elements, $k^{L}, k^{P}$ and $k^{H} \equiv a \eta$, and $x^{L}\left(k^{L}\right)=1, x^{L}\left(k^{H}\right)=0, x^{L}\left(k^{P}\right)=x^{H}\left(k^{P}\right)=1, x^{H}\left(k^{L}\right)=0$ and $x^{H}\left(k^{H}\right)=1$.

Proof: Take the equilibrium outside options of workers, $U^{L}$ and $U^{H}$, and the rental price, $\gamma$, as given. Observe that if net surplus from matching with type $j$ is positive, i.e. $\pi^{j}(k) \equiv J^{j}(k)-C k-V(k)>0$, then $x^{j}(k)=1$; if $\pi^{j}(k)<0$, then $x^{j}(k)=0$; and if $\pi^{j}(k)=0$, then $x^{j}(k) \in[0,1]$ for $j=H, L$ (recall that (8) ensures that $w^{j} \geq r U^{j}$, and this is incorporated in $J^{j}(k)$, so by construction the match is acceptable to workers, and that is why we only need to look at the firm's incentive to agree). In equilibrium, $V(k)=\gamma$. If $k \in \mathcal{K}$, then either $x^{L}(k)=1$ or $x^{H}(k)=1$. To see this note that if $x^{L}(k), x^{H}(k)<1$, then $J^{H}(k)-C k=J^{L}(k)-C k=\gamma$, and (4) implies $V(k)<\gamma$, which violates $k \in \mathcal{K}$.

Also observe that the equilibrium profit of matching with type $j$, $\tilde{\pi}^{j}(k) \equiv\left[A k^{\alpha} h_{j}^{1-\alpha}-w^{j}(k)\right] /(r+s)-C k-\gamma$ for $j=H, L$, is strictly concave (where I have substituted for $J^{j}(k)$ using $(5)$ ), so has a unique maximizer, $\tilde{k}^{j}$. Furthermore, for $k<\tilde{k}^{j}$, 
$\tilde{\pi}^{j}(k)$ is strictly increasing and for $k>\tilde{k}^{j}, \tilde{\pi}^{j}(k)$ is strictly decreasing. Also $\tilde{\pi}^{j}(0)<0$ and $\lim _{k \rightarrow \infty} \tilde{\pi}^{j}(k)<0$. Therefore, $\tilde{\pi}^{j}(k)=0$ for exactly two values of $k$. Denote these two values by $K_{L L}$ and $K^{L L}>K_{L L}$ for $j=L$ and $K_{H H}$ and $K^{H H}>K_{H H}$ for $j=H$. Observe that $K^{H H}>K^{L L}$. Second, note that for all $k \in \mathcal{K}, \min \left\{K_{L L}, K_{H H}\right\}<k<K^{H H}$. Suppose this were not the case, then the firm would never produce with any worker (i.e. $x^{j}(k)=0$ ) and thus $V(k)<\gamma$.

Now suppose that $K_{H H} \leq K^{L L}$. Then, we have that for all $k \in \mathcal{K} \cap\left[0, K_{H H}\right], x^{H}(k)=0$, and therefore $x^{L}(k)=1$ (recall if $x^{H}(k)<1$, then $x^{L}(k)=1$ ), and for all $k \in \mathcal{K} \cap$ $\left(K^{L L}, K^{H H}\right], x^{H}(k)=1$ and $x^{L}(k)=0$.

Next, observe that for given $x^{H}$ and $x^{L}, V(k)$ is strictly concave in $k$. Therefore, $k \in \mathcal{K} \cap\left[0, K_{H H}\right)$ (i.e. $x^{H}=0$ and $x^{L}=1$ ) implies $\arg \max _{k^{\prime}} \tilde{\pi}^{L}(k)=k^{L}$ for a unique value. More explicitly (substituting for $C \equiv(1-\beta) /(r+s)$ ):

$$
k^{L}=\arg \max _{k}\left\{A k^{1-\alpha}-(1-\beta) k-\max \left\langle r U^{L} ; \beta A k^{1-\alpha}\right\rangle\right\}
$$

In equilibrium, the firm will only agree to invest and start bargaining with the worker if $\tilde{\pi}^{L}(k)=J^{L}(k)-C k-V(k) \geq 0$, so $J^{L}(k)-V(k)>0$, and the outside option of the firm in (8) will never bind, which has been incorporated into (A2).

Similarly, $k \in \mathcal{K} \cap\left(K^{L L}, K^{H H}\right]$ implies $\arg \max _{k^{\prime}} \tilde{\pi}^{H}(k)=k^{H}$. Moreover, since there is only a unique maximizer of $\tilde{\pi}^{H}(k)$, which is the highest level of capital stock, the outside option of skilled workers cannot bind in the neighborhood of $k^{H}$, and by the above argument, the outside option of firms never bind. Therefore, the wage rule (8) becomes $w^{H}(k)=$ $\beta A k^{1-\alpha} \eta^{\alpha}$. This implies that $k^{H}=a \eta$.

Furthermore, we have that for all $k \in \mathcal{K} \cap\left[K_{H H}, K^{L L}\right], x^{H}(k)=1$ and $x^{L}(k)=1$. To see this, consider $k^{P} \in \mathcal{K} \cap\left[K_{H H}, K^{L L}\right]$, and by way of contradiction, suppose that $x^{L}\left(k^{P}\right)<1$. This can be true only if $\tilde{\pi}^{L}\left(k^{P}\right)=0$, then using (4), whave $V\left(k^{P}\right)=$ $\left[q \lambda\left(J^{H}\left(k^{P}\right)-C k^{P}\right)\right] /(r+q \lambda)$. Also from (4), we have $V\left(k^{H}\right)=\left[q \lambda\left(J^{H}\left(\dot{k}^{H}\right)-C k^{H}\right)\right] /(r+$ $q \lambda)$. By the fact that $k^{H}$ maximizes $J^{H}\left(k^{H}\right)-C k^{H}$, we have $J^{H}\left(k^{H}\right)-C k^{H}>J^{H}\left(k^{P}\right)-$ $C k^{P}$. Therefore, $V\left(k^{P}\right)<V\left(k^{H}\right)$, so $k^{P}$ cannot be in $\mathcal{K}$, yielding a contradiction. Hence $x^{L}\left(k^{P}\right)=1$. A similar argument establishes that $x^{H}\left(k^{P}\right)=1$, completing the proof of the claim in this paragraph.

Finally, since unskilled workers can get at most jobs with $k^{L}$ and $k^{P}>k^{L}$, their 
outside option when bargaining with a $k^{P}$-firm cannot bind (i.e. $\beta A\left(k^{P}\right)^{1-\alpha}>U^{L}$ ), so in the neighborhood of $k^{P},(8)$ becomes $w^{L}(k)=\beta A k^{1-\alpha}$. Therefore, substituting for $C \equiv(1-\beta) /(r+s)$, and incorporating the fact that the outside option of the firm is non-binding, $k^{P}$ is given as:

$$
\begin{aligned}
k^{P}= & \arg \max _{k}\left\{(1-\lambda)(1-\beta)\left(A k^{1-\alpha}-k\right)\right. \\
& \left.+\lambda\left(A k^{1-\alpha} \eta^{\alpha}-(1-\beta) k-\max \left\langle r U^{H} ; \beta A k^{1-\alpha} \eta^{\alpha}\right\rangle\right)\right\}
\end{aligned}
$$

Finally consider the case where $K_{H H}>K^{L L}$. Then $\mathcal{K} \cap\left(K_{H H}, K^{L L}\right)=\emptyset$, and the rest of the argument applies as it is, but in this case $x^{H}=1$ and $x^{L}=0$, or $x^{H}=0$ and $x^{L}=1$, so $\mu^{P}=0$.

Proof of Existence: Lemma A1 proved that in any equilibrium the characterization given in Proposition 3 is true, so I only have to prove the existence of a steady state equilibrium. The following equations define a steady state:

$$
\begin{gathered}
u^{H}=\frac{s}{s+p\left(\mu^{H}+\mu^{P}\right)} \\
u^{L}=\frac{s}{s+p\left(\mu^{L}+\mu^{P}\right)} \\
\gamma=\max \left\langle V\left(k^{H}\right), V\left(k^{L}\right), V\left(k^{P}\right)\right\rangle \\
\mu^{H}=G\left[V\left(k^{H}\right)-\gamma\right] \\
\mu^{L}=G\left[V\left(k^{L}\right)-\gamma\right]
\end{gathered}
$$

where $G($.$) is the following correspondence: G(\xi)=0$, if $\xi<0$; and $G(\xi)=[0,1]$, if $\xi=0$; and $G(\xi)=1$, if $\xi>0$. And finally, we have $k^{L}$ given by (A2), $k^{P}$ given by (A3), $\lambda$ given by $(10)$, and $\mu^{L}+\mu^{H}+\mu^{P}=1$. Also, recall that $k^{H}=a \eta$. These equations form a nine equation system defining nine variables, and define upper hemi continuous correspondences. Moreover, since there is a potential continuum of firms, any correspondence that is not convex valued can be made so by standard randomization arguments. Moreover, all variables live in closed, bounded and non-empty sets: $u^{H}, u^{L} \in[0,1], \lambda \in[0,1], \mu^{j} \in[0,1]$, and $k^{L}, k^{P} \in[0, \bar{K}]$ where $A \bar{K}^{1-\alpha} \eta^{a} /(r+s)=C \bar{K}$, (since $k>\bar{K}$ would lose money even without paying wages). Finally, to see that $\gamma \in[0, \Gamma]$, recall that $k \leq \bar{K}$ for all $k \in \mathcal{K}$, thus $V(k)$ is uniformly bounded and so is $\gamma$, and I denote this upper bound by $\Gamma$. Therefore, 
this nine equation system maps from a closed, bounded and non-empty subset of $\mathbb{R}^{9}$ into itself by means of an upper hemi continuous convex valued mapping. By Kakutani's fixed point theorem, this mapping has a fixed point which is a steady state equilibrium.

Details for a Pure Separating Equilibrium $\left(\mu^{L}=0\right)$ : A separating equilibrium with no unskilled jobs, i.e. with $\mu^{L}=0$, exists, when even $\mu^{H}=1$ does not make opening an unskilled or pooling job profitable. $\mu^{H}=1$ implies, $u^{L}=1$ and $u^{H}=s /(s+p)$. Therefore: $\lambda^{*}=s \phi /[s+p(1-\phi)]$. Next, we find $\eta^{*}$ such that when $\eta=\eta^{*}$ and $\lambda=\lambda^{*}$ firms are indifferent between unskilled and skilled jobs, that is (12) holds. This gives:

$$
\eta^{*}=\frac{(1-\phi)(s+p)[(r+s)(s+p(1-\phi)+q s \phi]}{\phi s[(r+s)(s+p(1-\phi)+q(1-\phi)(s+p)]}
$$

Then, we find $\eta^{* *}$ such that when $\eta=\eta^{* *}$ and $\lambda=\lambda^{*}$, a pooling job yields as much profit as a skilled job (i.e. $\left.V\left(k^{P}\right)=V\left(k^{H}\right)\right)$. This gives:

$$
\eta^{* *}=\frac{(1-\phi)(s+p)\left[(r+s)(s+p(1-\phi)+q s \phi]^{\alpha}\right.}{[s+p(1-\phi)]^{\alpha}(\phi s)^{\alpha}-s \phi\left[(r+s)(s+p(1-\phi)+q s \phi]^{\alpha}\right.}
$$

We are in a pure separating equilibrium, if $\eta>\max \left\{\eta^{*}, \eta^{* *}\right\}$. (A9) and (A10) define downward sloping curves in the $(\phi-\eta)$ space, so $\max \left\{\eta^{*}, \eta^{* *}\right\}$ also defines a downward sloping curve as obtained in Figure 2. 


\section{Notes}

$1 *$ Department of Economics, Massachusetts Institute of Technology, 50 Memorial Drive, Cambridge, MA 02142. I am grateful to three anonymous referees, and to Joshua Angrist, Brian Bell, Peter Diamond, Michael Kremer, Frank Levy, Steve Pischke, Jim Robinson, Matthew Shapiro, Robert Shimer, Jaume Ventura and various seminar participants for comments and useful suggestions. I also thank Matthew Barmack for help with the PSID data, Francesco Caselli for Figure 4 and David Autor for extracts from the decennial censuses. Maciej Dudek, Jonathan Dworak, John Johnson and John Romalis provided excellent research assistance. Finally, I gratefully acknowledge financial support from National Science Foundation, Grant No. SBR-9602116 and World Economic Laboratory at MIT.

${ }^{1}$ Statistical Abstracts of the U.S., 1995, Table 662. See also Stephen Nickell and Brian Bell (1995), Murphy and Robert H. Topel (1987). The unemployment rates have decreased recently due to sustained high growth of the U.S. economy but are not at their 1970 levels.

${ }^{2}$ Katz and Murphy (1992) show that in the short-run a higher of supply of skilled workers reduces the skill premium. The forces I emphasize instead operate over a longer time frame as capital and job composition adjust.

${ }^{3} \mathrm{An}$ alternative interpretation is that there are many different types of firms, indexed by the variable $k$. In equilibrium, only the types that will make the highest profits will enter. Also note that the main results hold if the firm incurs some cost $c_{1} k$ when choosing its capacity, and also incurs the production costs $c k$, but the analysis becomes more complicated. If $c=0$ so that all costs are incurred before matching, the static model would not work, but the dynamic model would give similar results.

${ }^{4}$ Random matching is plausible in this context. Since education and skills are imperfectly correlated, firms cannot easily target skilled workers, and targeting the highly educated workers will not be as profitable since many of those are unskilled. See Section II.D for an 
extension where high capacity firms are more likely to meet skilled workers.

${ }^{5}$ To see this, consider the aggregate production function: $Y=A K^{1-\alpha}\left[N_{L}^{\rho}+\zeta N_{H}^{\rho}\right]^{\alpha / \rho}$ where $N_{i}$ is the number of type $i$ workers, and $\rho>0$. An increase in $\zeta$ is skill-biased technical change. In the current model, since each firm employs either a skilled or an unskilled worker, an increase in $\zeta$ is equivalent to an increase in $\eta$.

${ }^{6}$ See Ariel Rubinstein (1982) and Avner Shaked and John Sutton (1984). The resulting sharing rule is different from Nash Bargaining normally used in search models, but may be argued to have somewhat better microfoundations. The main reason why I use it here is that it simplifies the algebra, without affecting the main results. See Acemoglu (1996) for a derivation of this wage rule in a search equilibrium.

${ }^{7}$ In reality, skills are not one-dimensional, and the changes in the structure of jobs may have started in the 1970's, first affecting the dimension of skills weakly correlated with education, and increasing residual inequality. This becomes more plausible when one considers that during this period, the supply of education increased very sharply, perhaps faster than the composition of jobs could have changed. Moreover, in practice, skilled and unskilled workers produce goods that are not perfect substitutes, implying that an increase in $\phi$ within the pooling region might reduce the relative wages of skilled workers. Therefore, the increase in educational attainment of workers may first reduce and then increase returns to education (see Acemoglu, 1998).

${ }^{8}$ The required education variable is bracketed, with the following brackets: $0-5,6-8$, $9-11,12,13-15,16,17$. The actual schooling variable is last grade completed. Because in 1985, actual schooling was only available in the individual files, for consistency, the education variable from the individual files has been used for 1976 and 1978 as well. Using the education variable from the family files for 1976 and 19778 does not change any of the results for these years. In all the calculations, the following values were substituted 
for the required education variable: 4 when the bracket was $0-5,8$ for the bracket $6-8,10$ when the bracket was 9-11 and 14 when the bracket was 13-15. These are the values used by Sicherman (1991) and using the means of the relevant brackets (e.g. 2.5 instead of 4) increases the magnitude of the changes from 1976 to 1985.

${ }^{9}$ The cells above the 75 th percentile include, among others, transport, mining and communication technicians; speciality occupations in transport, business and repair services, construction, finance, communications, hospital and mining, durable manufacturing sales occupations, and a variety of executive, administrative and managerial occupations. The cells below the 25 th percentile include handlers, laborers, and a variety service occupations in a variety of industries, including retail trade (which includes, among others, department and food stores, eating and drinking places), business and repair and social services.

${ }^{10}$ These are an extended version of the two digit occupations created by splitting some of the larger occupations along the three digit lines (see Acemoglu, 1997).

${ }^{11}$ Agriculture, forestry, fishing and public administration are excluded. These are industries aggregated consistently across the censuses and used in Autor, et al. (1997). I thank David Autor for providing me with these data.

${ }^{12}$ The numbers reported in Figure 4 do not weight industries. Caselli obtains very similar results when he weights each industry with the time-average of its employment, and when he uses other measures of dispersion, such as the log-variance. When he uses current employment as weights, the 90 th and 10th differential still increases by 8.4 percent between 1975 and 1990, but the log-variance shows a slight decline over this ped. Changes in the fraction of high skill workers over this period, however, make the log-variance with current weights harder to interpret. For example, even when the amounts of physical capital that skilled and unskilled workers use remain constant, a change in the fraction of skilled cmployees in the work force will have a first-order effect on this measure. 


\section{References}

Acemoglu, Daron "A Microfoundation For Increasing Returns in Human Capital Accumulation" Quarterly Journal of Economics, August 1996, 111 (3), pp 779-804.

Acemoglu, Daron "Good Jobs versus Bad Jobs: Theory and Some Evidence" MIT Working Paper, 1997.

Acemoglu, Daron and Robert Shimer, "Efficient Wage Dispersion" MIT and Princeton Working Paper, 1997.

Acemoglu, Daron "Why Do New Technologies Complement Skills? Directed Technical Change and Wage Inequality" forthcoming Quarterly Journal of Economics, November 1998, 113 (4).

Barron, John M., John Bishop and William C. Dunkelberg "Employer Search: The Interviewing and Hiring of New Employees" Review of Economics and Statistics, February 1985, 67 (1), pp 43-52.

Baskir, Lawrence M. and William Strauss, Chance and Circumstances: the Draft, the War and the Vietnam Generation, New York, Alfred Knopf, 1978.

Berman, Eli, John Bound and Zvi Griliches "Changes in the Demand for Skilled Labor Within U.S. Manufacturing Industries: Evidence from the Annual Survey of Manufacturing." Quarterly Journal of Economics, May 1994, 109 (2), pp 367-98.

Bound, John and George Johnson "Changes in the Structure of Wages in the 1980s: An Evaluation of Alternative Explanations" American Economic Review, June 1992, 82 (3), pp 371-92.

Burdett, Kenneth and Melvyn Coles "Marriage and Class" Quarterly Journal of Economics, February 1997, 102 (1), pp 115-140.

Cappelli, Peter "Technology and Skill Requirements: Implications for Establishment Wage Structures" New England Economic Review, May/June 1996, pp 139-153.

Cappelli, Peter and Steffanie Wilk "Understanding Selection Processes: Organization Determinants and Performance Outcomes" Wharton School Mimeo, 1997.

Caselli, Francesco "Technological Revolutions" University of Chicago, Mimeo, 1998.

Constantine, Jill M. and David Neumark "Training and the Growth of Wage Inequality" 
NBER Working Paper, No. 4729, 1994.

Davis, Steven J. "The Quality Distribution of Jobs in Search Equilibrium" University of Chicago Mimeo, 1996.

Diamond, Peter A. "Aggregate Demand Management in a Search Equilibrium" Journal of Political Economy, October 1982, 90 (5), pp 881-94.

Jovanovic, Boyan "Job Matching and the Theory of Turnover" Journal of Political Economy, October 1979, 87 (5), pp 972-990.

Juhn, Chinhui, Kevin M. Murphy and Brook Pierce "Wage Inequality and the Rise in Returns to Skill" Journal of Political Economy, June 1993, 101 (3), pp 410-442.

Katz, Lawrence F. and Kevin M. Murphy "Changes in Relative Wages: Supply and Demand Factors" Quarterly Journal of Economics., February 1992, 107 (1), pp 35-78.

Kremer, Michael and Eric Maskin "Segregation By Skill and the Rise in Inequality" MIT and Harvard Mimeo, 1997.

McPherson, Michael and Morton Schapiro, Keeping College Affordable: Government and Educational Opportunity, Washington, The Brookings Institution, 1991.

Mortensen, Dale T. "Property Rights and Efficiency in Mating, Racing and Related Games" American Economic Review, December 1982, 72 (5), 968-979.

Murnane, Richard J. and Frank Levy, Teaching the Basic New Skills, New York, The Free Press, 1996.

Murphy, Kevin M. and Robert H. Topel "The Evolution of Unemployment in the United States: 1968-1985" NBER Macroeconomics Annual, 1987, pp 7-58.

Nickell, Stephen and Brian Bell "The Collapse in the Demand For the Unskilled and Unemployment Across OECD Countries" Oxford Review of Economic Policy, Spring 1995, 11 (1), pp 40-62.

Pissarides, Christopher A. Equilibrium Unemployment Theory, Basil Blackwell, 1987.

Rubinstein, Ariel "Perfect Equilibrium in a Bargaining Model" Econometrica, January 1982, 50 (1), pp 97-109.

Sattinger, Michael "Assignment Models of Distribution of Earnings" Journal of Economic Literature, June 1993, 31 (2), pp 831-880. 
Sattinger, Michael "Search and the Efficient Assignment of Workers to Jobs" International Economic Review, May 1995, 36 (2), pp 283-330.

Shaked, Avner and John Sutton, "Involuntary Unemployment as a Perfect Equilibrium in a Bargaining Model" Econometrica, November 1984, 52 (6), pp 1341-64.

Shimer, Robert J. and Lones A. Smith "Search and Assortative Matching" MIT Mimeo, 1997.

Sicherman, Nachum "Overeducation in the Labor Market" Journal of Labor Economics, April 1991, 9 (2), pp 101-122.

Topel, Robert H. and Michael P. Ward "Job Mobility and the Careers of Young Men" Quarterly Journal of Economics, May 1992, 107 (2), pp 439-480. 
Table 1: Changes in Mismatch from 1976 to 1985

\begin{tabular}{|c|c|c|c|c|c|c|}
\hline \multirow[b]{2}{*}{ Year } & \multicolumn{3}{|c|}{ Number of Observations } & \multicolumn{3}{|c|}{$\begin{array}{c}\text { Panel B } \\
\text { Average Overeducation }\end{array}$} \\
\hline & $\begin{array}{r}(1) \\
1976 \\
\end{array}$ & $\begin{array}{r}(2) \\
1978 \\
\end{array}$ & $\begin{array}{r}(3) \\
1985 \\
\end{array}$ & $\begin{array}{r}(4) \\
1976 \\
\end{array}$ & $\begin{array}{r}(5) \\
1978 \\
\end{array}$ & $\begin{array}{r}(6) \\
1985 \\
\end{array}$ \\
\hline Overeducated & $\begin{array}{r}978 \\
{[0.40]}\end{array}$ & $\begin{array}{r}1028 \\
{[0.38]}\end{array}$ & $\begin{array}{r}1149 \\
{[0.39]}\end{array}$ & $\begin{array}{l}4.78 \\
(2.81)\end{array}$ & $\begin{array}{r}4.83 \\
(2.83)\end{array}$ & $\begin{array}{r}3.50 \\
(3.13)\end{array}$ \\
\hline Exact & $\begin{array}{r}1045 \\
{[0.43]}\end{array}$ & $\begin{array}{r}1174 \\
{[0.43]}\end{array}$ & $\begin{array}{r}1350 \\
{[0.46]}\end{array}$ & $\begin{array}{r}-0.05 \\
(0.42)\end{array}$ & $\begin{array}{r}-0.03 \\
(0.37)\end{array}$ & $\begin{array}{r}0.00 \\
(0.27)\end{array}$ \\
\hline Undereducated & $\begin{array}{r}426 \\
{[0.18]}\end{array}$ & $\begin{array}{r}517 \\
{[0.19]}\end{array}$ & $\begin{array}{r}438 \\
{[0.15]}\end{array}$ & $\begin{array}{r}-2.38 \\
(1.58)\end{array}$ & $\begin{array}{r}-2.42 \\
(1.63)\end{array}$ & $\begin{array}{r}-2.71 \\
(1.51)\end{array}$ \\
\hline Total & 2447 & 2719 & 2937 & $\begin{array}{r}1.47 \\
(3.40)\end{array}$ & $\begin{array}{r}1.35 \\
(3.42)\end{array}$ & $\begin{array}{r}0.966 \\
(3.02)\end{array}$ \\
\hline $\begin{array}{l}\text { Variance of } \\
\text { Overeducation }\end{array}$ & 11.6 & 11.7 & 9.1 & & & \\
\hline $\begin{array}{l}\text { Absolute Deviation } \\
\text { of Overeducation }\end{array}$ & 2.3 & 2.3 & 1.8 & & & \\
\hline
\end{tabular}

Note: All data from Panel Study of Income Dynamics. Sample includes male heads of households in employment, between the ages of 18 and 60. Overeducation is defined as actual education minus required education. The last two rows give the variance and average absolute deviation of overeducation in each of the three years. Proportion of the total is given in square brackets in the first three columns and standard deviations in parentheses in the last three columns. 
Table 2: Changes in the Composition of Employment, 1983-1993

\begin{tabular}{|c|c|c|c|c|c|c|}
\hline \multirow[b]{2}{*}{ Year } & \multicolumn{5}{|c|}{ Percentiles } & \multirow{2}{*}{$\begin{array}{r}W T: \text { weight } \\
\text { at the tails } \\
25 \text { th }+(1-75 \text { th }) \\
\end{array}$} \\
\hline & 10 th & 25 th & 50 th & 75 th & 90th & \\
\hline 1983 & 7.4 & 16.0 & 47.0 & 80.8 & 92.2 & 35.2 \\
\hline 1984 & 7.3 & 15.7 & 46.3 & 80.5 & 91.9 & 35.2 \\
\hline 1985 & 7.4 & 15.8 & 46.0 & 80.2 & 91.8 & 35.6 \\
\hline 1986 & 7.3 & 15.9 & 45.8 & 80.1 & 91.7 & 35.8 \\
\hline 1987 & 7.2 & 15.8 & 45.8 & 79.9 & 91.6 & 35.8 \\
\hline 1988 & 7.1 & 15.8 & 45.6 & 79.6 & 91.5 & 36.2 \\
\hline 1989 & 7.3 & 16.0 & 45.9 & 79.6 & 91.3 & 36.4 \\
\hline 1990 & 7.2 & 16.2 & 46.2 & 79.5 & 91.4 & 36.7 \\
\hline 1991 & 7.5 & 16.5 & 46.5 & 79.2 & 91.2 & 37.3 \\
\hline 1992 & 7.7 & 17.0 & 46.9 & 79.7 & 91.9 & 37.3 \\
\hline 1993 & 7.8 & 17.1 & 47.0 & 79.5 & 91.8 & 37.6 \\
\hline
\end{tabular}

Notes: The numbers are the cumulative percentage of workers employed in the one-digitindustry-one-digit-occupation cell at the indicated percentile of the job distribution. The cells are ranked according to average residual wages between 1983 and 1993 . Residual wages are obtained from a regression of real wages on four education dummies, a quartic in experience, sex, race, and a dummy for those living in a metropolitan area. The total number of cells is 174 , which excludes those with less than 200 observations between 1983 and 1993. The last column gives a measure of the weight at the tails of the employment distribution, $W T$. WT is defined as the sum of the fraction of people employed at the bottom 25 percent and top 25 percent cells. All calculations are from the Outgoing Rotation Group Files of the Current Population Survey, and use CPS weights. 


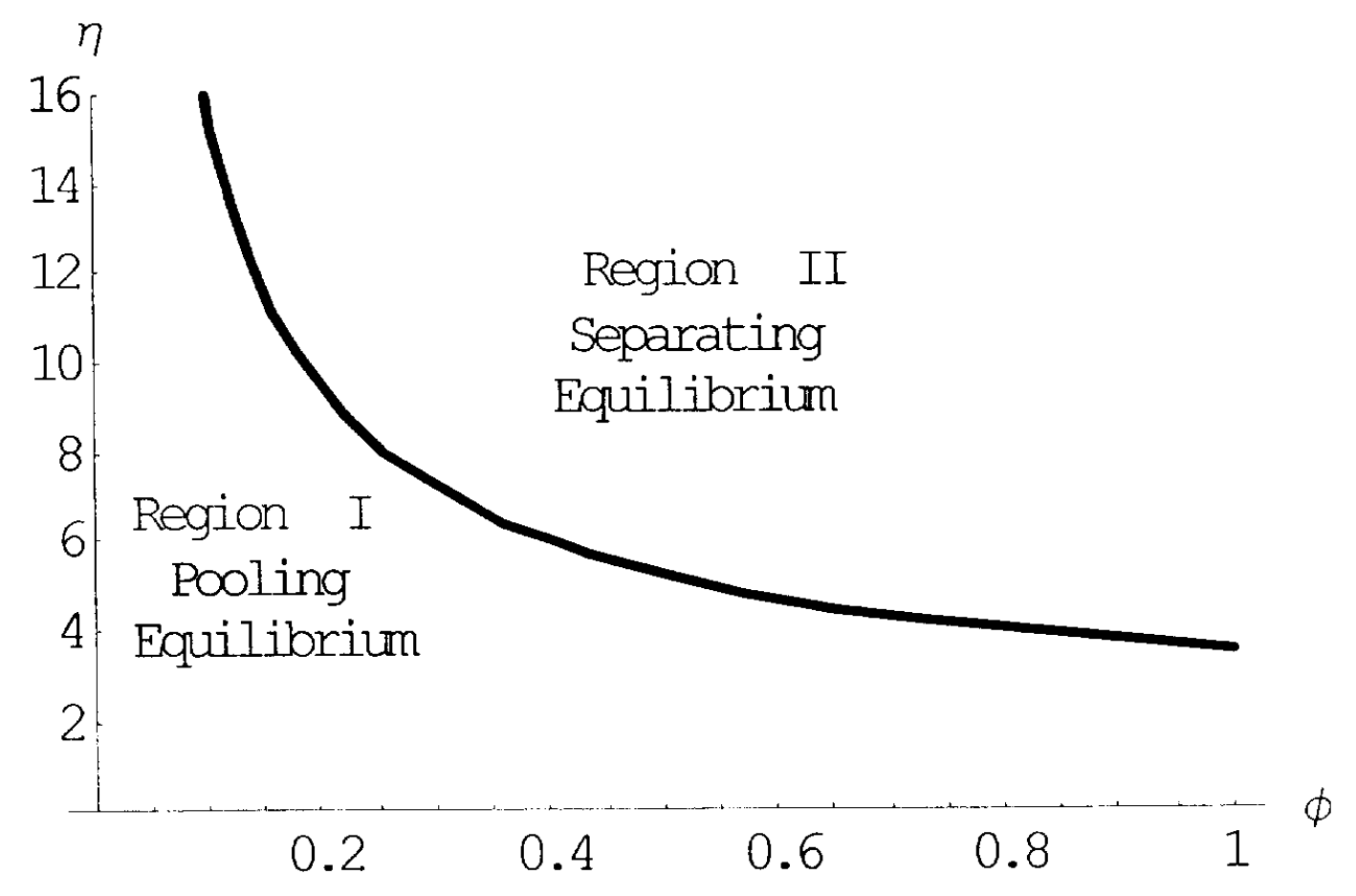

Figure 1: Pooling and Separating Equilibria in the Static Model for $\alpha=0.4$. 


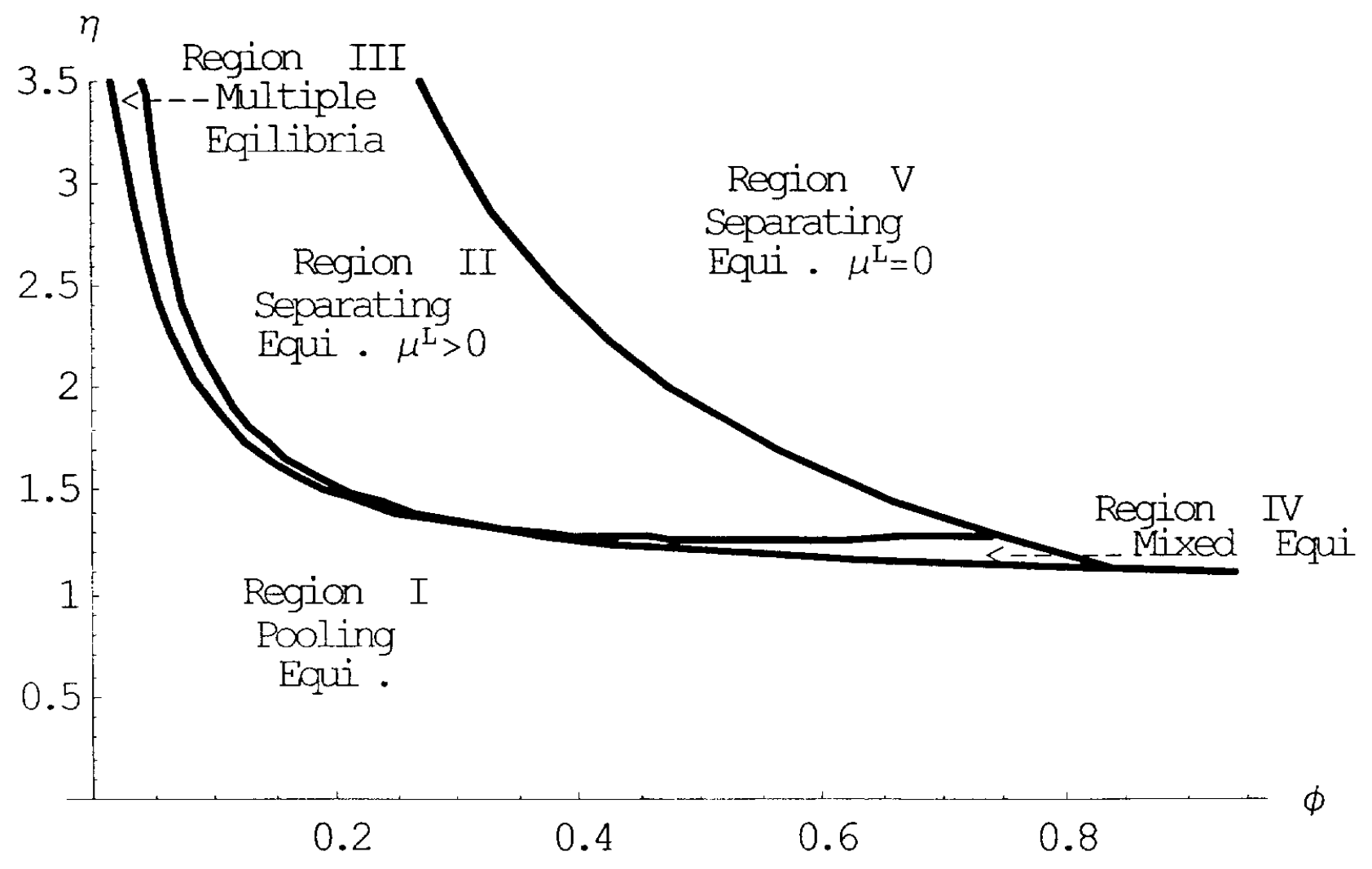

Figure 2: Different Types of Equilibria in the Dynamic Model, Parameterized for $\alpha=0.4, p=5, q=5, r=0.05, \beta=0.5$ and $A=1$. 


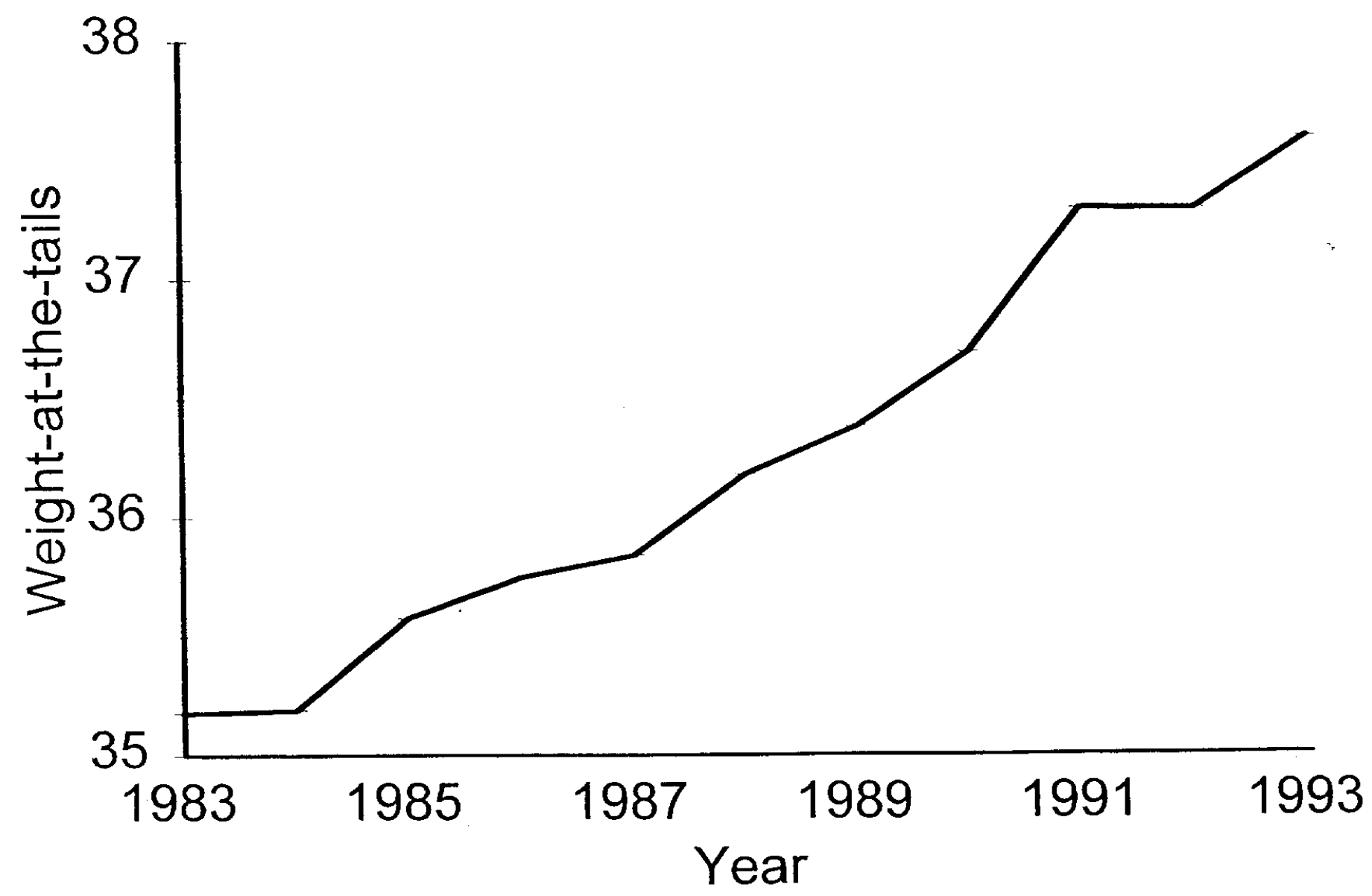

Figure 3: This figure plots $W T$ (weight at the tails), which is the total fraction of employment in the top 25 th and bottom 25 th percent industry-occupation cells. Data from Table 2. 


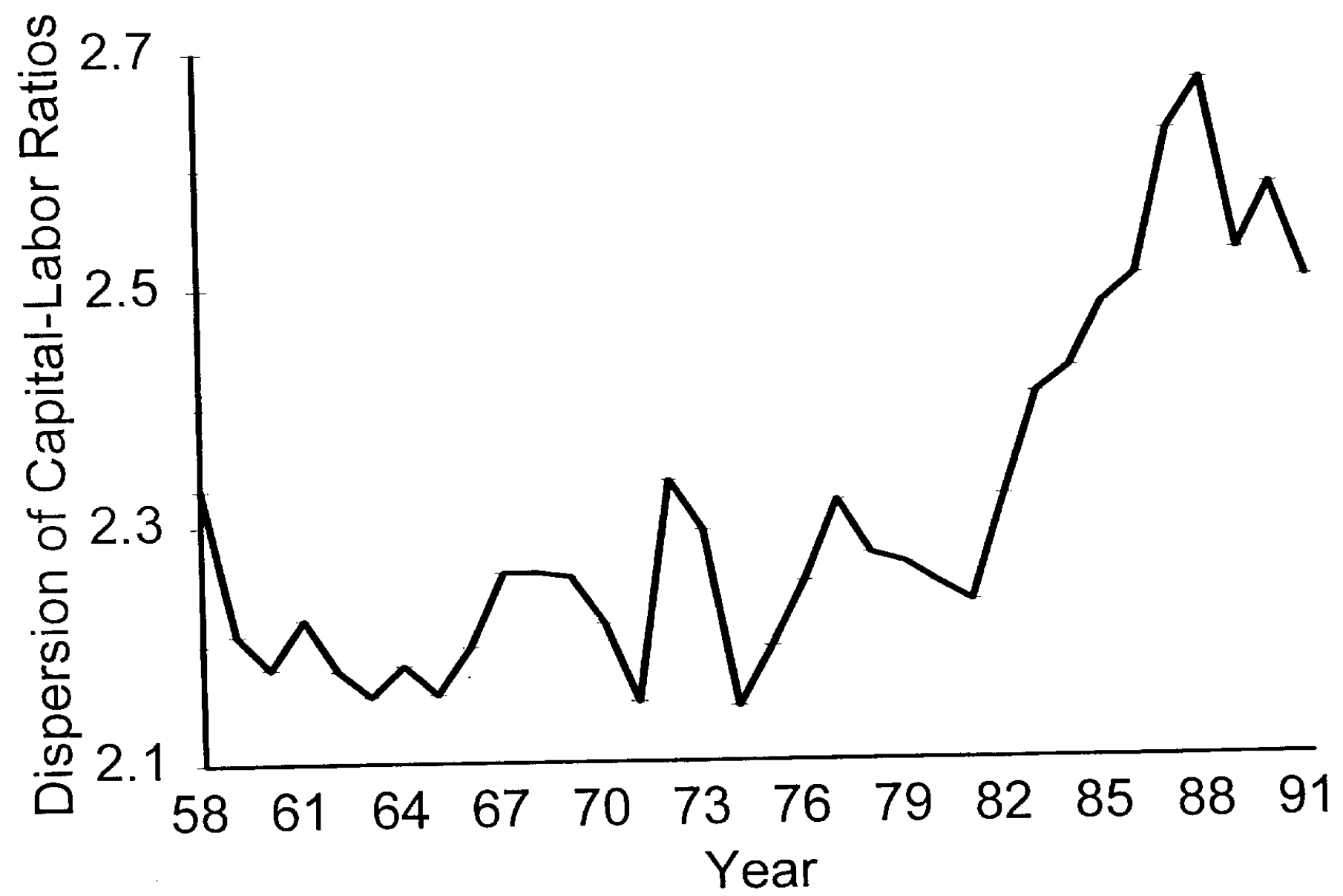

Figure 4: Log difference of the 90th and 10th percentiles of the distribution of the dollar value of equipment capital to employment ratios across 450 four-digit manufacturing industries. This figure is taken form Caselli (1998). The change from 1975 to 1995 is $17.5 \%$. 